\title{
Insights into characteristics, sources, and evolution of submicron aerosols during harvest seasons in the Yangtze River delta region, China
}

\author{
Y. J. Zhang ${ }^{1,2}$, L. L. Tang ${ }^{1,2}$, Z. Wang ${ }^{1}$, H. X. Yu ${ }^{3}$, Y. L. Sun ${ }^{4}$, D. Liu ${ }^{5}$, W. Qin ${ }^{2}$, F. Canonaco ${ }^{6}$, A. S. H. Prévôt ${ }^{6}$, \\ H. L. Zhang ${ }^{7}$, and H. C. Zhou ${ }^{1}$ \\ ${ }^{1}$ Jiangsu Key Laboratory of Atmospheric Environment Monitoring and Pollution Control, School of \\ Environmental Science and Engineering, Nanjing University of Information Science and Technology, \\ Nanjing 210044, China \\ ${ }^{2}$ Jiangsu Environmental Monitoring Center, Nanjing 210036, China \\ ${ }^{3}$ State Key Laboratory of Pollution Control and Resource Reuse, School of the Environment, \\ Nanjing University, Nanjing 210093, China \\ ${ }^{4}$ State Key Laboratory of Atmospheric Boundary Layer Physics and Atmospheric Chemistry, \\ Institute of Atmospheric Physics, Chinese Academy of Sciences, Beijing 100029, China \\ ${ }^{5}$ Centre for Atmospheric Science, School of Earth, Atmospheric and Environmental Sciences, \\ University of Manchester, Manchester M13 9PL, UK \\ ${ }^{6}$ Laboratory of Atmospheric Chemistry, Paul Scherrer Institute, Villigen PSI 5232, Switzerland \\ ${ }^{7}$ Handix LLC, Boulder, CO 8031, USA \\ Correspondence to: L. L. Tang (lily3258@163.com)
}

Received: 19 January 2014 - Published in Atmos. Chem. Phys. Discuss.: 4 April 2014

Revised: 13 December 2014 - Accepted: 17 December 2014 - Published: 6 February 2015

\begin{abstract}
Atmospheric submicron particulate matter $\left(\mathrm{PM}_{1}\right)$ is one of the most significant pollution components in China. Despite its current popularity in the studies of aerosol chemistry, the characteristics, sources and evolution of atmospheric $\mathrm{PM}_{1}$ species are still poorly understood in China, particularly for the two harvest seasons, namely, the summer wheat harvest and autumn rice harvest. An Aerodyne Aerosol Chemical Speciation Monitor (ACSM) was deployed for online monitoring of $\mathrm{PM}_{1}$ components during summer and autumn harvest seasons in urban Nanjing, in the Yangtze River delta (YRD) region of China. $\mathrm{PM}_{1}$ components were shown to be dominated by organic aerosol (OA, 39 and $41 \%$ ) and nitrate (23 and $20 \%$ ) during the harvest seasons (the summer and autumn harvest). Positive matrix factorization (PMF) analysis of the ACSM OA mass spectra resolved four OA factors: hydrocarbon-like mixed with cooking-related $\mathrm{OA}(\mathrm{HOA}+\mathrm{COA})$, fresh biomass-burning OA (BBOA), oxidized biomass-burning-influenced $\mathrm{OA}(\mathrm{OOA}-\mathrm{BB})$, and highly oxidized OA (OOA); in particular the oxidized BBOA
\end{abstract}

contributes $\sim 80 \%$ of the total BBOA loadings. Both fresh and oxidized BBOA exhibited apparent diurnal cycles with peak concentration at night, when the high ambient relative humidity and low temperature facilitated the partitioning of semi-volatile organic species into the particle phase. The fresh BBOA concentrations for the harvests are estimated as $\mathrm{BBOA}=15.1 \times(\mathrm{m} / z \quad 60-0.26 \% \times \mathrm{OA})$, where $\mathrm{m} / \mathrm{z}$ (mass-to-charge ratio) 60 is a marker for levoglucosanlike species. The $(\mathrm{BBOA}+\mathrm{OOA}-\mathrm{BB}) / \Delta \mathrm{CO},(\Delta \mathrm{CO}$ is the $\mathrm{CO}$ minus background $\mathrm{CO}$ ), decreases as a function of $f_{44}$ (fraction of $m / z 44$ in OA signal), which might indicate that BBOA was oxidized to less volatile OOA, e.g., more aged and low volatility OOA (LV-OOA) during the aging process. Analysis of air mass back trajectories indicates that the high BB pollutant concentrations are linked to the air masses from the western (summer harvest) and southern (autumn harvest) areas. 


\section{Introduction}

Particulate matter (PM) that is suspended in the atmosphere as atmospheric aerosol plays a crucial role in the regional and global climate system (Ramanathan et al., 2001; Kaufman et al., 2002), air pollution (Sun et al., 2013), ambient visibility reduction (Watson, 2002), and human health (Ge et al., 2011). Significant amounts of PM can be generated from human activities. In particular, biomass-burning (BB) activities, e.g., forest fires, wildfire, and agricultural fires, can become the main sources of fine particulate matter $\left(\mathrm{PM}_{2.5}\right.$, particulates $\leq 2.5 \mu \mathrm{m}$ in aerodynamic diameter) and/or submicron particulate matter $\left(\mathrm{PM}_{1}\right.$, particulates $\leq 1 \mu \mathrm{m}$ in aerodynamic diameter) (Andreae and Merlet, 2001, Aiken et al., 2010; DeCarlo et al., 2010; Lee et al., 2010; Cubison et al., 2011; Reche et al., 2012; Bougiatioti et al., 2014). Agricultural residues burning is one of the most serious sources leading to severe air quality problems during harvest seasons in China (Li et al., 2007; Wang et al., 2009a; Du et al., 2011; Cheng et al., 2013; Ding et al., 2013). Moreover, China is an agricultural country which has 1.8 billion cultivated fields with a large amount of agricultural crop residue (Zhang et al., 2008). Recently, the use of agricultural residues as fuel in China declined. During harvest seasons, farmers usually harvest the crop in the daytime and then burn agricultural residues directly in their fields, which results in BB emissions. The investigation of the compositions, sources, and processes of atmospheric aerosol particles during harvest seasons is urgently needed to better understand the impact of aerosol particles from BB sources on air quality.

Organic aerosol (OA) composes a large fraction of atmospheric aerosol particles (Zhang et al., 2007). Combination of positive matrix factorization (PMF; Paatero, 1997) and a PMF evaluation tool (PET; Ulbrich et al., 2009) has been well used to identify and apportion the sources of OA in recent studies (e.g., Lanz et al., 2007; Ulbrich et al., 2009; Allan et al., 2010; Zhang et al., 2005a, 2011; Crippa et al., 2013, 2014; Sun et al., 2013). In addition, an $\mathrm{IGOR}^{\mathrm{TM}}$-based source finder (SoFi; Canonaco et al., 2013) with a multilinear engine algorithm (ME-2; Paatero, 1999) can also resolve the emission sources of OA. The current PMF and ME-2 method can only be employed to analyze OA data sets a posteriori (Sun et al., 2012; Zhang et al., 2011; Canonaco et al., 2013), but cannot be easily utilized in the real-time online estimation of atmospheric OA sources. To identify the sources of atmospheric OA online, an algorithm based solely on organic mass fragments, namely, $\mathrm{m} / \mathrm{z}$ (mass-to-charge ratio) $57\left(\right.$ mostly $\mathrm{C}_{4} \mathrm{H}_{9}^{+}$) and $m / z 44$ (mostly $\mathrm{CO}_{2}^{+}$), was developed to estimate hydrocarbon-like OA (HOA) and oxygenated OA (OOA), respectively (Zhang et al., 2005a, b; Ng et al., 2011c). Mohr et al. (2012) also identified cookingrelated OA (COA) in ambient data sets based on the fractions of COA tracers at $m / z 55$ (mostly $\mathrm{C}_{4} \mathrm{H}_{7}^{+}$) and $m / z 57$ organic mass fragments. Biomass-burning organic aerosol (BBOA) is one of the major atmospheric OA species during $\mathrm{BB}$ peri- ods (Aiken et al., 2010; Allan et al., 2010). However, limited information on developing the tracer-based method a posteriori is available for estimating the source apportionment of BBOA.

The evolution processes of atmospheric OA, e.g., aging and/or oxidation, can significantly influence the physicochemical properties of OA (Aiken et al., 2008; Jimenez et al., 2009; Sun et al., 2011b). In the presence of BB source, various volatile and semi-volatile organic precursors can be emitted from the field burning of agricultural wastes, and secondary organic aerosol (SOA) can be formed from these precursors rapidly (Jimenez et al. 2009; Grieshop et al., 2009; Heringa et al., 2011; Kawamura et al., 2013). Furthermore, BB plumes can be mixed with urban and regional pollutants during aging processes (DeCarlo et al., 2010; Cubison et al., 2011). In addition, the secondary formation, atmospheric transport, and diffusion, as well as the mass loadings and oxidation state of ambient OA, can also be affected by the aging processes of OA (Jimenez et al., 2009; Cubison et al., 2011; Sun et al., 2011b). Thus, it is important to investigate the evolution of OA and the evolution process effects in order to better understand the nature of atmospheric OA.

This study investigates the characteristics of $\mathrm{PM}_{1}$ species using an Aerodyne Aerosol Chemical Speciation Monitor (ACSM), and OA mass spectra are analyzed with the PMF model during summer and autumn harvests in the Yangtze River delta (YRD) region; the evolution of OA and the effects of the evolution process on PM burden were also investigated. Combination of back trajectory analysis and local wind meteorology was used to investigate the origins.

\section{Experimental methods}

\subsection{Sampling site description}

With a population of more than 8 million and an area of $\sim 6597 \mathrm{~km}^{2}$, Nanjing is a representative Chinese city in terms of the pollution characteristics of the YRD region. Local and regional air pollution events frequently occur in Nanjing, mainly caused by emissions of mixed aerosols from fossil fuel burning, residential activities, and agricultural residues burning (Wang et al., 2009a; Ding et al., 2013). In this study, an abundance of data were collected in urban Nanjing $\left(118^{\circ} 46^{\prime} \mathrm{N}, 32^{\circ} 05^{\prime} \mathrm{E}\right)$ from 1 to 15 June and 15 to $30 \mathrm{Oc}-$ tober 2013, corresponding to two harvest seasons in a year, namely, the summer wheat harvest and autumn rice harvest. The sampling site was located on the roof of a six-story building approximately $18 \mathrm{~m}$ above ground level, $\sim 15 \mathrm{~m}$ from the nearest heavy-traffic road, and $\sim 50 \mathrm{~m}$ from the nearest restaurants and residents. As a matter of fact, there is no agricultural field in the urban Nanjing areas. However, there are some agricultural fields in the rural areas around Nanjing (Supplement Fig. S1). This means that the urban Nanjing site is significantly influenced by the BB plumes originated from 
the rural areas. In addition, the local cooking and traffic emissions can also significantly affect the PM pollution in this sampling site. Therefore, in the presence of BB plumes, the mixed/complicated air pollution will occur in urban Nanjing during the harvest seasons.

\subsection{Instrumentation and data analysis}

\subsubsection{Measurements}

The ambient non-refractory submicron aerosol (NR-PM 1$)$ species, i.e., OA, nitrate, sulfate, ammonium, and chloride, were continuously measured using ACSM from 1 to 15 June and 15 to 30 October 2013. In addition, the measurement without significant agricultural burning impacts (little/negligible BB influence) was also performed at the same site from 1 to 8 July. Detailed descriptions of ACSM can be found in previous studies ( $\mathrm{Ng}$ et al., 2011a; Sun et al., 2012). Briefly, the ambient aerosols were drawn into the $1 / 2$ in. (outer diameter) stainless steel tube at a flow rate of $\sim 3 \mathrm{~L} \mathrm{~min}^{-1}$, of which $\sim 84 \mathrm{~cm}^{3} \mathrm{~min}^{-1}$ was sub-sampled into the ACSM. Moreover, ACSM was operated at a time resolution of about $15 \mathrm{~min}$ with a scan from $\mathrm{m} / \mathrm{z} 10$ to $150 \mathrm{amu}$ (atomic mass unit) at $500 \mathrm{~ms} \mathrm{amu}^{-1}$ rate, which corresponds to the settings of Sun et al. (2012).

An online analyzer, monitoring of aerosols and gases (MARGA, model ADI 2080 Applikon Analytical B. V. Corp., the Netherlands), was deployed to measure the mass concentrations of a major water-soluble inorganic ion (potassium ion, $\mathrm{K}^{+}$) in the aerosols. A $\mathrm{PM}_{2.5}$ cyclone inlet was used to remove coarse particles. Ambient air was sampled into a liquid with a flow rate of $16.7 \mathrm{~L} \mathrm{~min}^{-1}$. The detection limit of $\mathrm{K}^{+}$is $0.09 \mu \mathrm{g} \mathrm{m}^{-3}$. The Met One BAM-1020 and the 7-wavelength aethalometer (Magee AE31) were also employed to measure $\mathrm{PM}_{1}$ and ambient atmospheric black carbon (BC) in $\mathrm{PM}_{2.5}$, respectively. $\mathrm{CO}$ was measured using a gas analyzer (Thermo Scientific, Model 48i). Ambient meteorological parameters including ambient temperature $(T)$, relative humidity $(\mathrm{RH})$, precipitation, wind speed (WS), and wind direction (WD) were obtained from a ground level meteorology station located on the same six-story building as the sampling site.

Daily fire locations used in this study were available from MODIS (Moderate-resolution Imaging Spectroradiometer) mounted on NASA's Terra and Aqua satellites, NASA's Earth Observing System (EOS) (https://earthdata.nasa.gov/ data/near-real-time-data/firms). MODIS can present fire distributions in details at $1 \mathrm{~km}$ resolution through Fire Information for Resource Management System (FIRMS) on global scale (Justice et al., 2002; Kaufman et al., 2003). As shown in Figs. S1-S2, all agricultural fire locations (red dots) in the YRD region were detected by the remote-sensing retrieval of MODIS from 1 to 15 June and 15 to 30 October 2013 (https://firms.modaps.eosdis.nasa.gov/firemap/).

\subsubsection{ACSM data analysis}

An ACSM data analysis software package, ACSM Local (ver. 1.5.2.0.0, released 25 April 2012) written in Wavemetrics IGOR $^{\mathrm{TM}}$, was used to analyze the ACSM data set. More details of procedures have been described in the studies of $\mathrm{Ng}$ et al. (2011a) and Sun et al. (2012). The ACSM calibration is based on a combination of a differential mobility analyzer (DMA, TSI model 3080) and condensation particle counter (CPC, TSI model 3775) for the ionization efficiency (IE) and relative ionization efficiencies (RIEs). Pure ammonium nitrate $\left(\mathrm{NH}_{4} \mathrm{NO}_{3}\right)$ particles (size selected by $300 \mathrm{~nm}$ ) are used for the calibration of the instrument because $\mathrm{NH}_{4} \mathrm{NO}_{3}$ vaporizes with $100 \%$ efficiency ( $\mathrm{Ng}$ et al., 2011a). The RIEs values usually used in aerosol mass spectrometer (AMS) ambient concentration calculations (Canagaratna et al., 2007) are the default values of organics (1.4), nitrate (1.1), sulfate (1.2), and chloride (1.3) in this study. Moreover, the RIE value of ammonium is 7.04 , and the response factor (RF) value of nitrate is $3.96 \times 10^{-11}$ in this study. In addition, the mass concentrations of ambient aerosol need to be corrected for particle collection efficiency (CE) (Middlebrook et al., 2011). $\mathrm{CE}=0.5$ is found to be representative with data uncertainties generally within $20 \%$ (Canagaratna et al., 2007; Middlebrook et al., 2011). The CE values observed in previous studies range from 0.43 to 1 , due to (a) shape-related collection losses at the vaporizer from inefficient focusing of nonspherical particles, (b) particle losses at the vaporizer because of bouncing of solid particles before they are completely vaporized, and (c) particle losses in the aerodynamic inlet as a function of particle diameter (Allan et al., 2004; Zhang et al., 2005b; Canagaratna et al., 2007; Middlebrook et al., 2011). In this study, we selected the CE value for OA, nitrate, sulfate, ammonium, and chloride, respectively, according to the equation $\mathrm{CE}=\max (0.45,0.0833+0.9167 \times \mathrm{ANMF})(\mathrm{Mid}-$ dlebrook et al., 2011), in which ANMF is the mass fraction of $\mathrm{NH}_{4} \mathrm{NO}_{3}$ (ANMF) measured by the ACSM.

The PMF method, combining PMF2 executables with the PMF Evaluation Tool (PET) (Ulbrich et al., 2009), was applied to analyze OA data sets from the ACSM. More details of procedure for the PMF model can be found in previous studies (Ulbrich et al., 2009; Zhang et al., 2005a, 2011). Due to large interferences of internal standard of naphthalene at $m / z$ 's $127-129$, only $m / z<120$ was used for PMF analysis (Sun et al., 2012, 2013). Based on the OA data set from the ACSM, the PMF analysis was performed for 1 to 7 factors. A summary of the PMF results is presented in Figs. S6-S15. For the chosen number of factors, rotational forcing parameter (fpeaks) were varied in steps of 0.1 from -1 to 1 for the data of the summer and autumn harvest. Four OA factors, i.e., hydrocarbon-like mixed with cooking $\mathrm{OA}(\mathrm{HOA}+\mathrm{COA})$, fresh biomass-burning $\mathrm{OA}(\mathrm{BBOA})$, oxidized biomass-burning-influenced OA (OOA-BB), and highly oxygenated OA (OOA), were resolved in this study. The HOA + COA was considered as a factor mixing with 
$\mathrm{COA}$ and traffic HOA in the 4-factor solution, while the $\mathrm{HOA}+\mathrm{COA}$ factor splits into factors with very similar time series from a 5- to a 7-factor solution. This means that the PMF analysis of the ACSM OA mass spectra has difficulties distinguishing the COA from the traffic HOA in this study. Sun et al. (2010) and Sun et al. (2012) also found a similar phenomenon for distinguishing COA from traffic HOA in a quadrupole AMS (Q-AMS) and an ACSM OA mass spectra using PMF analysis in Beijing. For the 3-factor solution, BBOA might be mixed with OOA-BB, while the 4-factor solution (which contained two BB-related BBOA factors, i.e., BBOA and OOA-BB) seemed to be better (more details can be found in Sect. 3.2) than the other solutions. The detailed list of explanations on the reasons for the selection of the 4factor solution can be found in Tables S4-S5. In addition, the OA source apportionment for the two harvests will be further discussed in Sect. 3.2.

\subsubsection{Back trajectory analysis}

Impacts of various source regions on the PM pollution during the harvest seasons have been investigated using the HYbrid Single-Particle Lagrangian Integrated Trajectory (HYSPLIT4) model developed by National Oceanic and Atmospheric Administration (NOAA)/Air Resources Laboratory (ARL) (Draxler and Rolph, 2003). Accordingly, $48 \mathrm{~h}$ back trajectories (BTs) at $500 \mathrm{~m}$ arrival height above ground level were calculated every $2 \mathrm{~h}$ starting at China standard time (CST) using a Trajectory Statistics (TrajStat) software developed by Wang et al. (2009b). In this study, the $48 \mathrm{~h}$ back trajectories of air masses were used for further analysis.

\section{Results and discussion}

\subsection{Meteorological factors and $\mathrm{PM}_{1}$ components}

\subsubsection{Time series of meteorological factors and $\mathbf{P M}_{1}$ components}

Figure 1 shows the time series of NR-PM $M_{1}$ species and $\mathrm{BC}$ in the presence of different meteorological conditions during the harvest seasons in urban Nanjing, i.e., WS, $\mathrm{WD}, \mathrm{RH}, T$, and precipitation. During the summer harvest, the average values were $70.7 \pm 15.3 \%, 3.7 \pm 1.7 \mathrm{~m} \mathrm{~s}^{-1}$, and $23.4 \pm 4.1{ }^{\circ} \mathrm{C}$ for the ambient $\mathrm{RH}$, WS, and $T$, respectively. In the autumn harvest, the average values were $54.3 \pm 13.7 \%, 2.6 \pm 1.4 \mathrm{~m} \mathrm{~s}^{-1}$, and $18.1 \pm 3.6^{\circ} \mathrm{C}$ for the ambient RH, WS, and $T$, respectively. The frequency distribution of hourly averaged WD and WS throughout the summer and autumn harvests are shown in Fig. S2a-b.

As shown in Fig. S3, there is a strong correlation between the Met One $\mathrm{PM}_{1}$ measured by Met One BAM-1020 and the $\mathrm{PM}_{1}$ (i.e., $\left.\mathrm{NR}-\mathrm{PM}_{1}+\mathrm{BC}\right)$ mass concentrations $\left(r^{2}=0.88\right.$, slope $=1.11$, indicating that the ambient submicron aerosols consisted mainly of the NR-PM 1 and BC. Note that the mass
Table 1. Mean mass concentrations $\left(\mu \mathrm{g} \mathrm{m}^{-3}\right)$ and standard deviation (SD) of $\mathrm{PM}_{1}\left(\mathrm{NR}-\mathrm{PM}_{1}+\mathrm{BC}\right)$ species, OA components and meteorological factors (i.e., WS, $\mathrm{RH}$, and $T$ ) during the harvest seasons.

\begin{tabular}{|c|c|c|c|c|}
\hline \multirow[t]{2}{*}{ Species } & \multicolumn{2}{|c|}{ Summer harvest } & \multicolumn{2}{|c|}{ Autumn harvest } \\
\hline & Mean & SD & Mean & SD \\
\hline \multicolumn{5}{|c|}{ Aerosol species } \\
\hline $\mathrm{NO}_{3}$ & 9.0 & 7.1 & 9.2 & 6.2 \\
\hline $\mathrm{SO}_{4}$ & 5.0 & 2.4 & 4.7 & 2.5 \\
\hline $\mathrm{NH}_{4}$ & 7.0 & 3.5 & 6.4 & 3.5 \\
\hline Chl & 0.4 & 0.9 & 0.7 & 0.8 \\
\hline OA & 15.4 & 12.8 & 22.3 & 17.5 \\
\hline $\mathrm{BC}$ & 3.2 & 2.2 & 6.0 & 3.8 \\
\hline $\mathrm{PM}_{1}$ & 38.5 & 24.3 & 46.4 & 27.0 \\
\hline \multicolumn{5}{|c|}{ OA components } \\
\hline $\mathrm{HOA}+\mathrm{COA}$ & 2.2 & 2.4 & 5.7 & 7.6 \\
\hline $\mathrm{BBOA}$ & 1.1 & 1.0 & 1.5 & 1.6 \\
\hline $\mathrm{OOA}-\mathrm{BB}$ & 4.1 & 4.6 & 6.5 & 7.3 \\
\hline OOA & 7.1 & 3.6 & 6.6 & 3.2 \\
\hline \multicolumn{5}{|c|}{ Meteorological factors } \\
\hline $\mathrm{WS}\left(\mathrm{m} \mathrm{s}^{-1}\right)$ & 3.5 & 1.7 & 2.6 & 1.4 \\
\hline $\mathrm{RH}(\%)$ & 70.7 & 15.3 & 54.3 & 13.7 \\
\hline$T\left({ }^{\circ} \mathrm{C}\right)$ & 24.1 & 4.1 & 18.1 & 3.5 \\
\hline
\end{tabular}

concentration of $\mathrm{BC}$ in the $\mathrm{PM}_{1}$ may be overestimated due to the fact that the mass concentration of $\mathrm{BC}$ was measured by the 7-wavelength aethalometer for $\mathrm{PM}_{2.5}$. An overestimation was previously suggested by Huang et al. (2011). The average $\mathrm{PM}_{1}$ mass for the summer harvest is $38.5 \mu \mathrm{g} \mathrm{m}^{-3}$ with an hourly average ranging from 3.6 to $270.6 \mu \mathrm{g} \mathrm{m}^{-3}$, which is similar to that observed in the autumn harvest $\left(42.3 \mu \mathrm{g} \mathrm{m}^{-3}\right)$ with an hourly average ranging 8.1 to $191.5 \mu \mathrm{g} \mathrm{m}^{-3}$. Indeed, $\mathrm{PM}_{1}$ consisted of OA (39\%), nitrate $(23 \%)$, ammonium $(16 \%)$, sulfate $(12 \%), \mathrm{BC}(8 \%)$, and chloride $(1 \%)$ during the summer harvest. During the autumn harvest, $\mathrm{PM}_{1}$ was composed of OA $(41 \%)$, nitrate $(20 \%)$, ammonium $(14 \%)$, sulfate $(11 \%), \mathrm{BC}(13 \%)$, and chloride $(1 \%)$. Table 1 presents a comparison of the average composition of $\mathrm{PM}_{1}$ between the summer harvest and autumn harvest periods. The average bulk composition of $\mathrm{PM}_{1}$ during the summer harvest shows a similar dominance of OA to the PM pollution during the autumn harvest, but lower mass fractions for other species except nitrate. Overall, those species with the exception of $\mathrm{BC}$ also show a similar contribution between the summer and autumn harvest to the $\mathrm{PM}_{1}$ mass, suggesting that the PM pollution could be affected by similar pollution sources for the two harvests.

As shown in Fig. 1, all aerosol species exhibited very dynamic variations in mass concentrations due to the changes of source emissions, meteorology factors (such as WD, RH, $T$, and planetary boundary layer height), photochemical reactions, and regional transport (e.g., the BB plumes). For ex- 


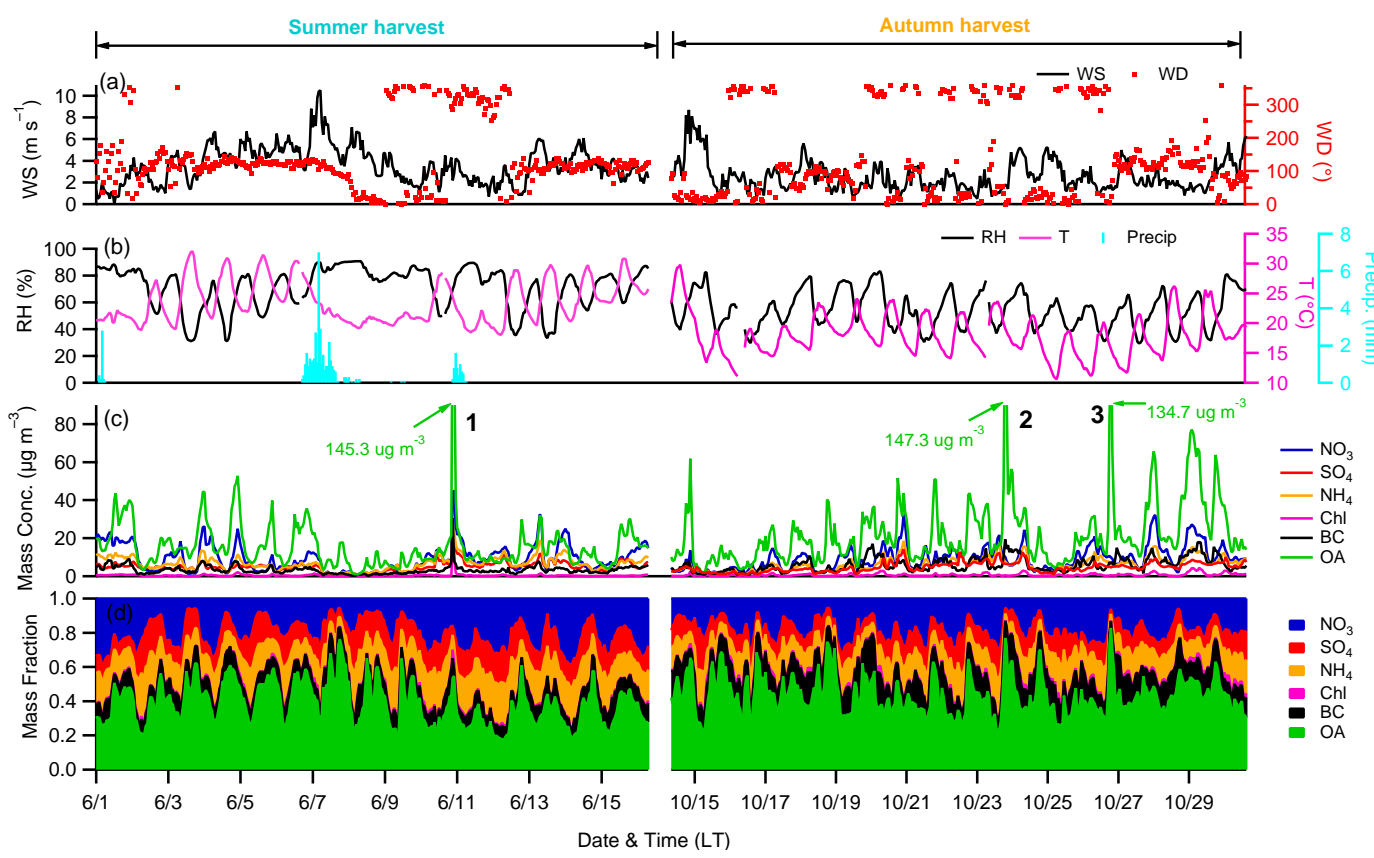

Figure 1. Time series of (a) wind speed (WS) and wind direction (WD); (b) relative humidity (RH), temperature (T) and precipitation (Precip); (c) submicron aerosol species, i.e., organic aerosol (OA), ammonium $\left(\mathrm{NH}_{4}\right)$, nitrate $\left(\mathrm{NO}_{3}\right)$, sulfate $\left(\mathrm{SO}_{4}\right)$, chloride $(\mathrm{Chl})$ and black carbon (BC); and (d) mass fraction during the harvest seasons. Three case events are marked and discussed in the text.

ample, the aerosol species dramatically reduced because of the quick removal processes associated with heavy wet scavenging (e.g., 6-8 June) during the summer harvest. However, the wet scavenging plays a minor role in changing aerosol loadings with little precipitation during the autumn harvest. OA shows a significant dynamic variation in mass concentrations during the harvest seasons (Fig. 1c), likely due to the changes of source emissions (such as cooking, traffic and/or BB emissions). There are three sharp peaks during the summer harvest (case 1) and autumn harvest (case 2 and case 3). The relationships between the PM pollution, meteorology, and chemical composition are presented in three case events (Table S1). The case 1, at 21:00-22:00 LT on 10 June, with the highest $\mathrm{PM}_{1}$ mass $\left(253.1 \mu \mathrm{g} \mathrm{m}{ }^{-3}\right)$ during the summer harvest is characterized by high loadings of $\mathrm{K}^{+}$, $\mathrm{BBOA}, \mathrm{OOA}-\mathrm{BB}$, chloride, and $\mathrm{BC}$, indicating the significant impacts of agricultural burning from the northwest of Nanjing (Fig. 1). Apart from the high loadings of BB-related components, such as BBOA, OOA-BB, and $\mathrm{K}^{+}$seen in the case 2 and case 3 periods, local source-related components, e.g., $\mathrm{HOA}+\mathrm{COA}$ and $\mathrm{BC}$, also present high concentrations. This suggests that both local primary source emissions and regional BB plumes dominate the PM pollution during the case 2 and case 3 periods. Therefore, those findings indicate that indeed BB contributes significantly in the area during the specific time period.

\subsubsection{Diurnal variations of meteorological factors and $\mathrm{PM}_{1}$ components}

Figure 2 depicts the diurnal variations of the meteorological factors, i.e., RH, $T$, and $\mathrm{WS}$, and $\mathrm{PM}_{1}$ species (including OA, nitrate, sulfate, ammonium, chloride, and BC). Generally, the diurnal variations of the meteorological parameters and $\mathrm{PM}_{1}$ species are similar during the summer and autumn harvest. However, the ambient RH and $T$ during summer harvest were higher than those during autumn harvest. OA obviously exhibits three peaks occurring between 06:0008:00, 11:00-14:00, and 19:00-22:00 LT, which is in agreement with the contributions of pollution sources, e.g., traffic, cooking and/or BB (Allan et al., 2010; Huang et al., 2012; Sun et al., 2012; Crippa et al., 2013). More details of the diurnal variations of the OA components will be presented in Sect. 3.2.

Sulfate does not show any significant diurnal trend during both summer and autumn harvest, and shows a similar concentration during the two harvests. This means the non-volatile character and regional pollution of sulfate in the YRD region during the summer and autumn harvest are analogous. A similar diurnal trend of sulfate was also found by Huang et al. (2012) in the eastern YRD region. Nitrate presents in a higher fraction of the total $\mathrm{PM}_{1}$ compared with sulfate, yet with lower concentrations in the afternoon and higher concentrations in the evening during the harvests. Similarly, nitrate also shows a similar concentration for the two harvests during the whole day; in addition, 

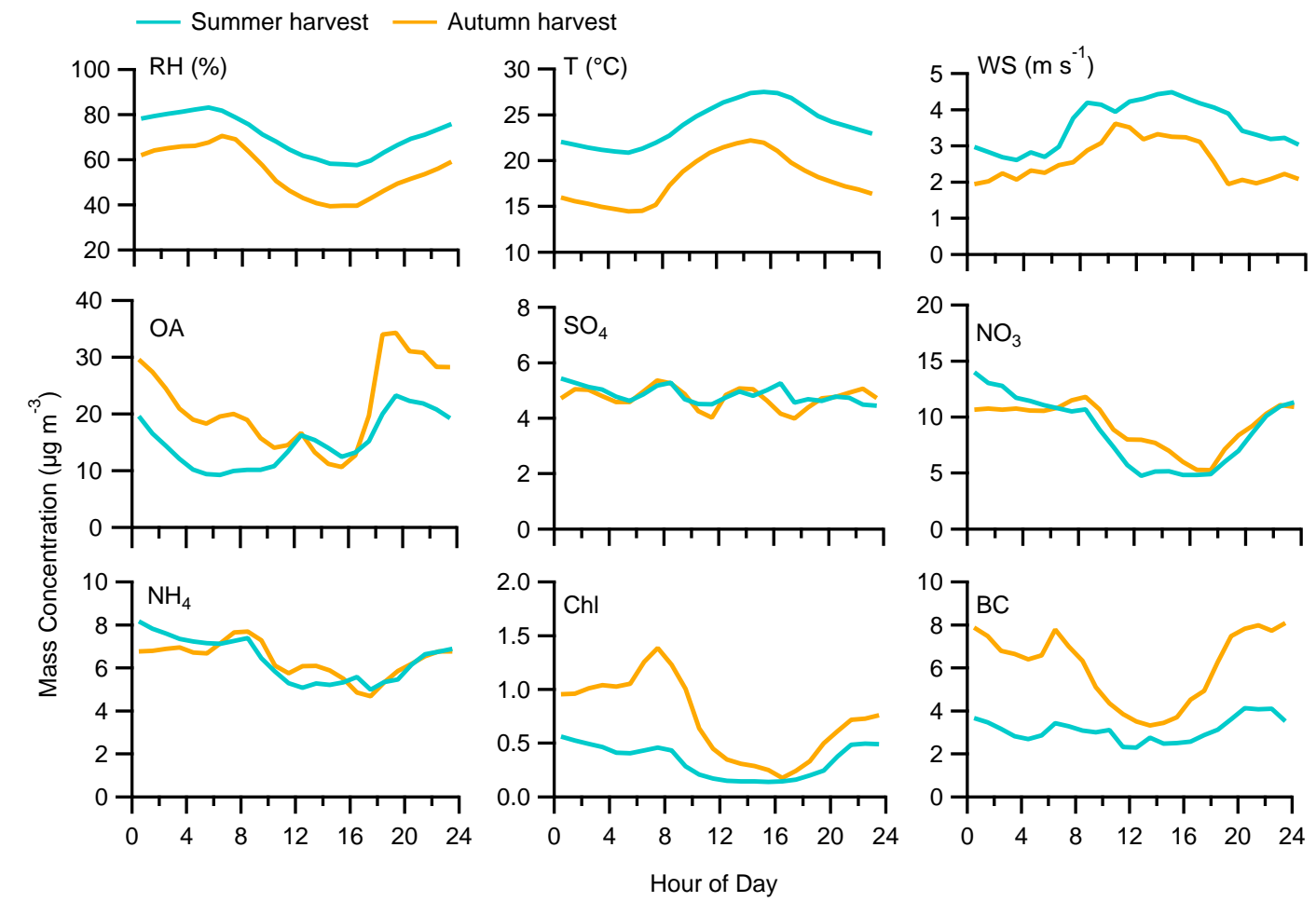

Figure 2. Diurnal variation patterns of meteorological factors (i.e., $\mathrm{RH}, T$, and WS) and $\mathrm{PM}_{1}$ species including organic aerosol (OA), nitrate $\left(\mathrm{NO}_{3}\right)$, sulfate $\left(\mathrm{SO}_{4}\right)$, ammonium $\left(\mathrm{NH}_{4}\right)$, chloride $(\mathrm{Chl})$, and black carbon $(\mathrm{BC})$ during the harvest seasons.

chloride shows a similar diurnal cycle with nitrate during the two harvest seasons. This is in accordance with the volatile and gas-particle partitioning properties of ammonium nitrate and ammonium chloride dependent on ambient $T$ and $\mathrm{RH}$ (Lanz et al., 2007; Sun et al., 2011b, 2012). This also reflects that the photochemical production of $\mathrm{HNO}_{3}$ cannot compensate for the evaporative loss at the relatively high $T$ conditions during the two harvests, which is similar to previous results observed by Huang et al. (2012) in the eastern YRD region and Sun et al. (2012) in Beijing. Furthermore, the higher boundary layer may dilute their loadings during the daytime, and then influence their diurnal cycles (Sun et al., 2012). Chloride is mainly ammonium chloride $\left(\mathrm{NH}_{4} \mathrm{Cl}\right)$ and/or organic chlorine-containing species (Huffman et al., 2009; Huang et al., 2012; Sun et al., 2012). During the harvest seasons, the evening high values of nitrate and chloride might be affected by the BB emissions and/or formed via gas-phase and aqueous-phase oxidations.

$\mathrm{BC}$ shows a classic diurnal variation with higher loadings appearing in early morning and during nighttime, which is consistent with traffic rush hours in early morning (07:0008:00 LT) and during nighttime (20:00-21:00 LT). As in previous studies, atmospheric $\mathrm{BC}$ is strongly associated with combustion emissions (including traffic and BB source emissions), particular for BB periods (Sandradewi et al., 2008; Liu et al., 2011, 2014; Crippa et al., 2013). Therefore, the reason for the peak values of $\mathrm{BC}$ during the nighttime may be also caused by the BB emissions during the harvest seasons, apart from the effect of traffic source on the BC loadings. The lower concentrations of $\mathrm{BC}$ in the afternoon can be associated with the dilution effects of higher planetary boundary layer and reduced traffic emissions.

\subsection{Organic source apportionment}

Four OA factors (i.e., HOA + COA, BBOA, OOA-BB, and OOA) were identified, as illustrated in Figs. 3 and 4. The mean mass concentrations of $\mathrm{HOA}+\mathrm{COA}$, BBOA, OOA$\mathrm{BB}$, and $\mathrm{OOA}$ during the harvest seasons are presented in Table 1. HOA + COA, BBOA, OOA-BB, and OOA accounted on average for $15 \%(28 \%), 7 \%(7 \%), 29 \%(33 \%)$ and $49 \%$ $(32 \%)$ of the total OA mass concentrations during the summer (autumn) harvest, respectively.

\subsubsection{Hydrocarbon-like and cooking-emissions-related OA (HOA + COA)}

The prominent hydrocarbon ion series of $\mathrm{C}_{\mathrm{n}} \mathrm{H}_{2 \mathrm{n}+1}^{+}$and $\mathrm{C}_{\mathrm{n}} \mathrm{H}_{2 \mathrm{n}-1}^{+}$(e.g., 27, 29, 41, 43, 55, 57) obtained from the mass spectrum were characterized as components of HOA (Zhang et al., 2005a, 2011; Mohr et al. 2009; Allan et al., 2010). As reported in previous studies, $m / z 57\left(\mathrm{C}_{3} \mathrm{H}_{5} \mathrm{O}^{+}\right.$and/or $\left.\mathrm{C}_{4} \mathrm{H}_{9}^{+}\right)$ and $m / z 55\left(\mathrm{C}_{3} \mathrm{H}_{3} \mathrm{O}^{+}\right.$and/or $\left.\mathrm{C}_{4} \mathrm{H}_{7}^{+}\right)$are commonly considered as tracers for the primary organic emissions of combus- 

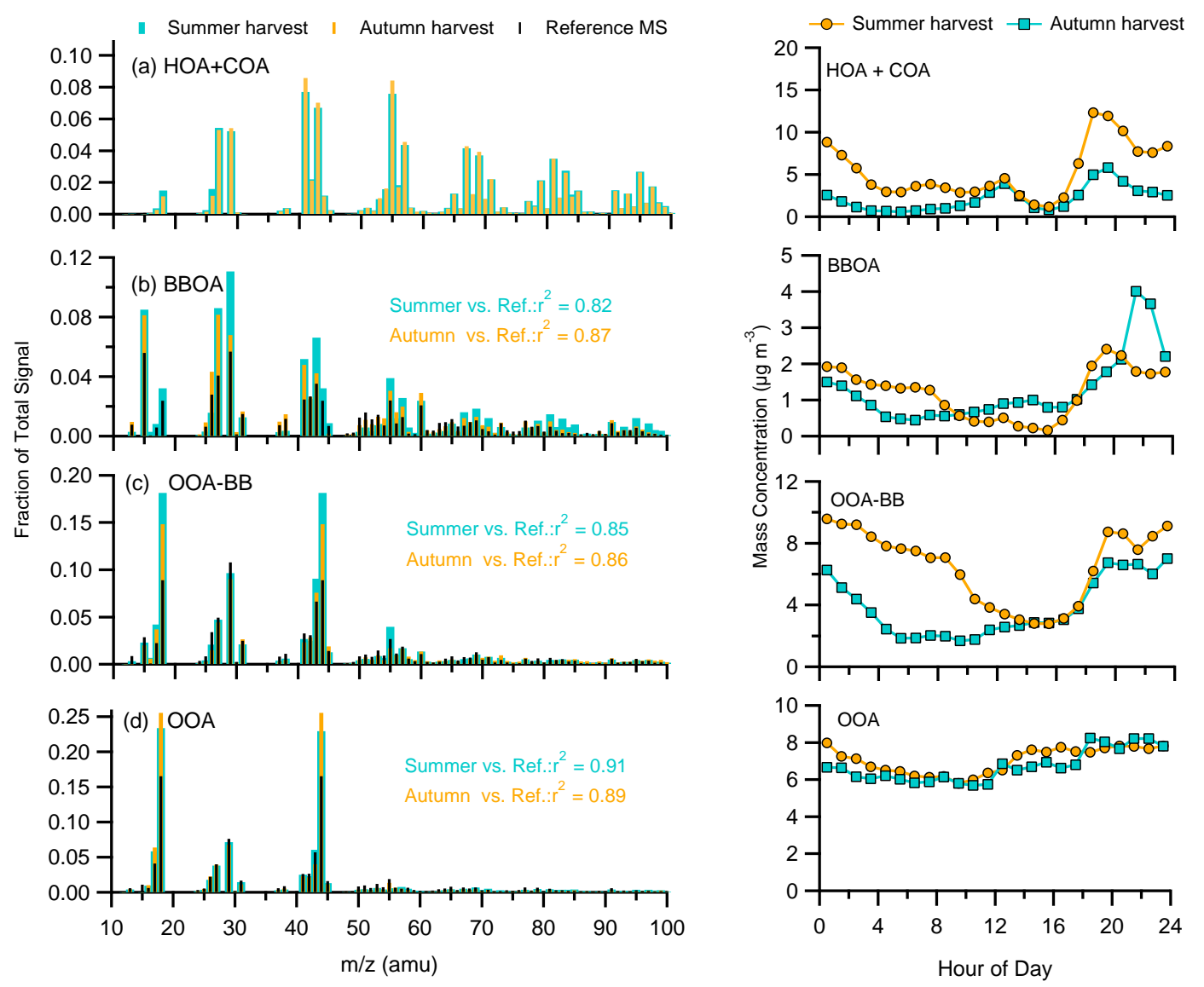

Figure 3. Mass spectra profiles (left) and diurnal variations (right) of four OA factors, i.e., hydrocarbon-like and cooking-emissions-related $\mathrm{OA}(\mathrm{HOA}+\mathrm{COA})$, fresh biomass-burning (BB) OA (BBOA), oxygenated BB-influenced OA (OOA-BB), and highly oxygenated OA (OOA). Note that reference mass spectra (MS) are obtained from the results by Crippa et al. (2013), and oxygenated BBOA components have been resolved $\left(\mathrm{OOA}_{2}-\mathrm{BBOA}\right)$.

tion sources in urban areas, including COA and HOA (Zhang et al., 2005a; Ng et al., 2010, 2011b; He et al., 2010; Sun et al., 2012, 2013; Hu et al., 2013). It is found that there is no significant difference in the mass spectrum between the summer harvest and the autumn harvest (Fig. 3a). Compared with traffic-like OA (Liu et al., 2011; Crippa et al., 2013), the mass spectrum obtained in the present study shows a higher $\mathrm{m} / \mathrm{z}$ 55/57 ratio. Previous studies indicated that high $m / z$ 55/57 together with a unique diurnal variation can be used as a diagnostics for the presence of COA (Mohr et al., 2009; Allan et al., 2010; Sun et al., 2012). The mass spectrum of HOA in this study is characterized by more abundant ions, i.e., $m / z 41$ (mainly $\mathrm{C}_{3} \mathrm{H}_{5}^{+}$), $m / z 55$ (mainly $\mathrm{C}_{4} \mathrm{H}_{7}^{+}$), and $m / z 57$ (Fig. 3a), which is similar to the characteristics of COA mass spectrum measured by He et al. (2010). As shown in Fig. 3, the diurnal variation of $\mathrm{HOA}+\mathrm{COA}$ shows two pronounced peaks corresponding to noon (a weak peak) and evening traffic/cooking activities (a strong peak). Hence, $\mathrm{HOA}+\mathrm{COA}$ in this study refers to the sum of traffic-related HOA and COA. Similarly, Sun et al. (2010) and Sun et al. (2012) also found that HOA species in urban ambient were influenced by both traffic and cooking-like emissions.

\subsubsection{Fresh biomass-burning OA (BBOA)}

As shown in Fig. 3b, the mass spectrum of BBOA extracted in this study shows a prominent peak of $m / z, 60$ which is a well-known tracer ion for BB emissions (Alfarra et al., 2007; Aiken et al., 2009; Cubison et al., 2011; Huang et al., 2011; Liu et al., 2011). Levoglucosan was shown to contribute to $\mathrm{m} / \mathrm{z} 60$ and was found in large amounts in urban, suburban, and rural background atmosphere during BB periods (Maenhaut et al., 2012). In addition, the BBOA is also characterized by higher peaks at $m / z 27,29,41,43,55,57,77$, and 91 that are indicative of freshly emitted organic aerosol because fresh $m / z$ 43-m/z 57 can also be from BB-related emissions (Aiken et al., 2009; Heringa et al., 2011; Bougiatioti et al., 2014). For example, primary BBOA (P-BBOA) has a significant contribution from a non-oxygenated ion $\mathrm{C}_{3} \mathrm{H}_{7}^{+}$ at $m / z 43$, but not from an oxygenated ion $\mathrm{C}_{2} \mathrm{H}_{3} \mathrm{O}^{+}(\mathrm{m} / z$ 43) in smog chamber experiments by Heringa et al. (2011). 
The BBOA spectrum profiles with the lack of $m / z 44$ signal $\left(\mathrm{CO}_{2}^{+}\right)$during the summer and autumn harvest show high correlation $\left(r^{2}=0.82\right.$ and $\left.r^{2}=0.87\right)$ with a result in Paris (Crippa et al., 2013). Moreover, the spectrum of BBOA in this study is qualitatively similar to published BB spectra from the fresh BB smoke in a smog chamber (Grieshop et al., 2009). These findings suggest that this factor can be related to BBOA with low atmospheric oxidants, and thus this factor might be associated with fresh/primary BBOA during the harvests.

Using soluble $\mathrm{K}^{+}$as a tracer for BB has also been reported by previous analyses of BB campaign data (Gilardoni et al., 2009; Aiken et al., 2010; Du et al., 2011; Crippa et al., 2013). The time series of BBOA along with $\mathrm{K}^{+}$measured by MARGA is shown in Fig. 4b. BBOA is strongly correlated with $\mathrm{K}^{+}\left(r^{2}=0.95\right.$ and $\left.r^{2}=0.78\right)$ during the summer and autumn harvest, respectively (Fig. 5a), suggesting that $\mathrm{BBOA}$ and $\mathrm{K}^{+}$were from the same source. In addition, the diurnal variation of BBOA shows a pronounced peak at nighttime (Fig. 3), which is consistent with the effects of the BB emissions (Fig. 3). This means that BBOA contributes to primary organic aerosol (POA) mainly during the nighttime. This finding is also consistent with the habit of the farmers in the YRD region, i.e., they usually harvest wheat or rice in the daytime and burn off straw in the nighttime during the harvest seasons each year. In addition, chloride correlates well with BBOA $\left(r^{2}=0.61\right.$ and $\left.r^{2}=0.66\right)$ and $\mathrm{K}^{+}\left(r^{2}=0.60\right.$ and $r^{2}=0.64$ ) during the harvest seasons (Fig. S5). This suggests that chloride was mainly from the $\mathrm{BB}$ emissions and might be in the form of $\mathrm{KCl}$ during $\mathrm{BB}$ periods.

\subsubsection{Oxygenated OA (OOA) and oxidized BB-influenced OA (OOA-BB)}

The mass spectrum of both OOA components (Fig. $3 \mathrm{c}$ and d) was characterized by the prominent $\mathrm{C}_{x} \mathrm{H}_{\mathrm{y}} \mathrm{O}_{\mathrm{z}}^{+}$fragments, which has been denoted as being previously found in many AMS studies (Zhang et al., 2005a; Lanz et al., 2007; Sun et al., 2010; Crippa et al., 2013). The mass spectra of OOA by the prominent peak of $\mathrm{m} / \mathrm{z} 44$ (mainly $\mathrm{CO}_{2}^{+}$) (22.9 and $25.5 \%$ of the total OOA signal) during the summer and autumn harvest are strongly consistent with more oxidized OOA component determined $\left(r^{2}=0.91\right.$ and $r^{2}=$ 0.89, Fig. 3d) during a BB period in Paris (Crippa et al., 2013) and OOA components resolved at other urban sites (Lanz et al., 2007; Ulbrich et al., 2009).

In Figure $4 d$ the time series of OOA is compared with the sulfate mass loadings. A correlation was observed between time series of OOA and sulfate mass loadings $\left(r^{2}=0.60\right.$ and $r^{2}=0.46$; Fig. 6) during the summer and autumn harvests, respectively. Previous studies performed at various sites also showed that these two species were secondary with low volatility properties in the atmosphere (Zhang et al., 2005a; Lanz et al., 2007; Ulbrich et al., 2009; Sun et al., 2011a; Huang et al., 2012). Overall, the diurnal pattern of OOA shows a relatively stable trend throughout the whole day (Fig. 3). OOA often remains at a high concentration across several days until a change of air mass occurs, which shows a regional production (Sun et al., 2012, 2013). This may be the main reason causing the relatively stable trend through the whole day in this study. Nevertheless, OOA shows a slight increase at around 12:00-15:00, suggesting that more oxidized OOA might be formed by photochemical processing. OOA also exhibits higher loadings during the nighttime, probably caused by the aging of BB plumes, in which BB emissions will be further oxidized and begin to transition into OOA (Jimenez et al., 2009; DeCarlo et al., 2010). The uniform distribution of its concentrations is almost in association with an abundance of WD during the summer and autumn harvest (Fig. S4). This is strong proof for explaining the regional pollution of OOA in the YRD region during the harvest seasons.

Additionally, an oxygenated factor with the high degree of oxygenation during the summer and autumn harvest $(\mathrm{m} / \mathrm{z}$ $44,18.2$, and $14.5 \%$ of the total factor signal) in its mass spectrum has been resolved and identified as oxidized BBinfluenced OA (OOA-BB, Fig. 3c). The mass spectra of OOA-BB are characterized by both the oxidized ions $(\mathrm{m} / \mathrm{z}$ $18,29,43$, and 44) and the typical marker of BB $(\mathrm{m} / \mathrm{z}$ $60)$ during the summer and autumn harvest, which correlates well with those of $\mathrm{BB}$-emission-related $\mathrm{OOA}\left(\mathrm{OOA}_{2}\right.$ BBOA) $\left(r^{2}=0.85\right.$ and $\left.r^{2}=0.86\right)$ during BB periods at an urban site in Paris (Crippa et al., 2013). It is also highly similar to the mass spectrum of the aged BBOA identified by DeCarlo et al. (2010) for airborne measurements during the MILAGRO (Megacity Initiative: Local and Global Research Observations) campaign, and very much in agreement with the aged BBOA from a BB experiment in a chamber study by Heringa et al. (2011). In addition, the mass spectrum of OOA-BB shows more oxygenated degree, compared to mass spectrum of fresh/primary BBOA from PMF analysis in the atmosphere, from laboratory open wood burning (Aiken et al., 2009) and from BBOA in this study. The OOA$\mathrm{BB}$ spectrum in this study is also very similar to the spectrum of the aged OA produced from aged biomass smoke in a smog chamber (Grieshop et al., 2009). OOA-BB presents a pronounced diurnal cycle with the highest concentration in the evening and early morning during the harvests (Fig. 3), which is very consistent with the diurnal variations of BBOA. This means that the OOA-BB production from open BB is rapid in short timescales with the high $\mathrm{RH}$ and low $T$ conditions in the nighttime. OOA-BB also shows relatively low loadings in the daytime, due to the dilution effects by enhanced mixing in the planetary boundary layer and the evaporative loss of semi-volatile components.

As shown in Fig. 4c, the OOA-BB time series strongly correlates with $\mathrm{K}^{+}$and $\Delta m / z 60$ (i.e., $m / z 60-0.26 \% \times \mathrm{OA}$, in which the applied metric of background $f_{60}=0.26 \%$ of OA will be discussed in Sect. 3.4) during the summer and autumn harvests, supporting the $\mathrm{BB}$ influence. In addition, the sum of BBOA and OOA-BB also shows high correlation with $\mathrm{K}^{+}$ 


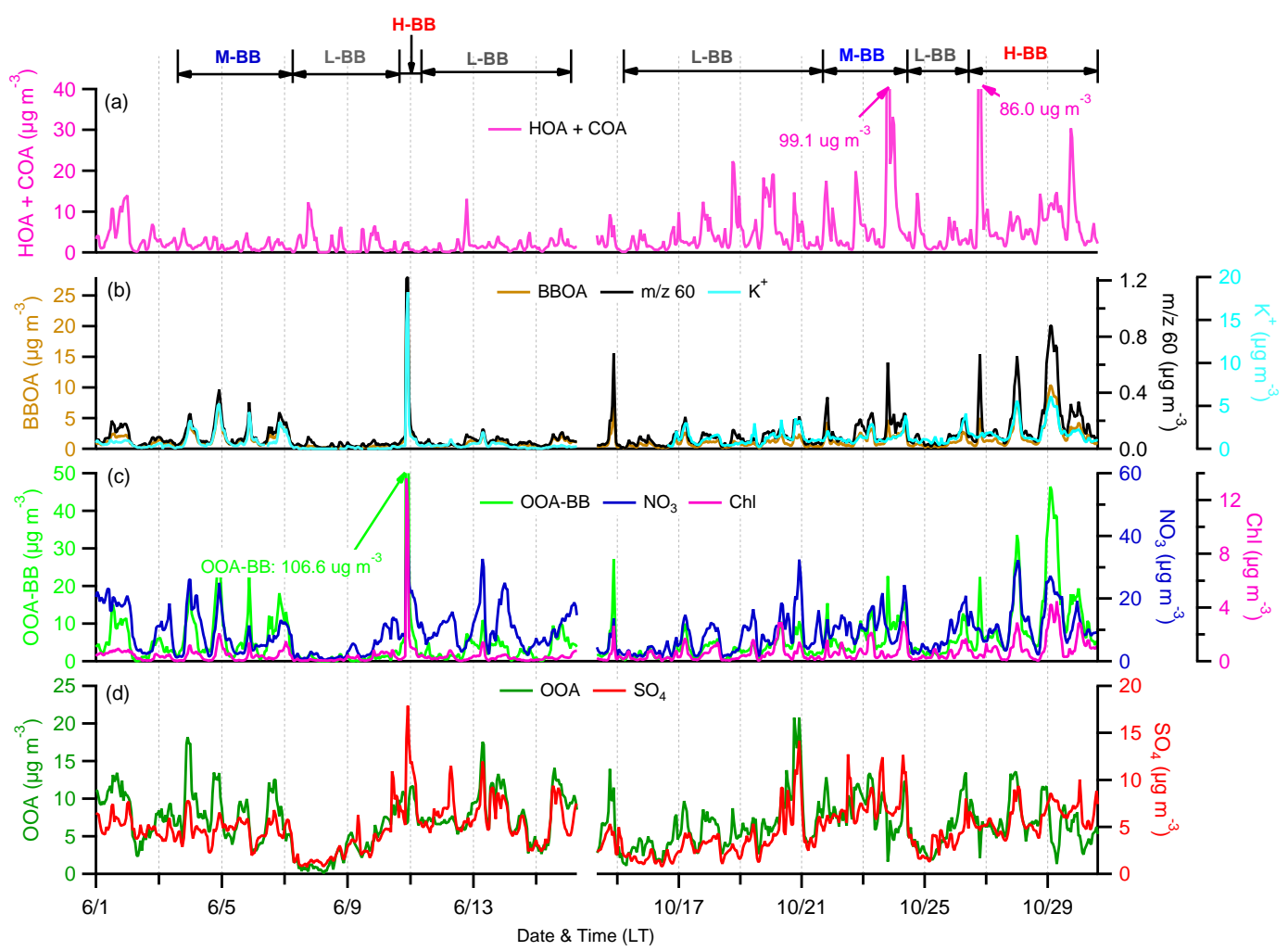

Figure 4. Time series of OA factors (left) and relevant tracer species (right): (a) HOA + COA; (b) BBOA and a surrogate of levoglucosan $(\mathrm{m} / \mathrm{z}, 60)$ and potassium ion $\left(\mathrm{K}^{+}\right)$; (c) OOA-BB, nitrate and chloride; (d) OOA and $\mathrm{SO}_{4}$. Note that different BBOA mass concentrations for a low biomass-burning period (L-BB), medium biomass-burning period (M-BB), and high biomass-burning period (H-BB).

and $\Delta m / z 60$ for the two harvests (Fig. 5a-b). This suggests that OOA-BB represents an atmospheric mixture of BBOA and OOA, which is similar to a recent HR-ToF-AMS (highresolution time-of-flight aerosol mass spectrometer) study by Crippa et al. (2013). It is interesting that OOA-BB correlates well with nitrate $\left(r^{2}=0.30\right.$ and $\left.r^{2}=0.54\right)$, yet shows lower correlation with sulfate $\left(r^{2}=0.16\right.$ and $\left.r^{2}=0.30\right)$ for the summer and autumn harvest, respectively (Fig. 6). Also, the time series of OOA-BB shows a similar trend as chloride during the two harvest seasons (Fig. 4c). This implies an indication of the semi-volatile character of OOA-BB, which is consistent with the results from a recent field study in the eastern Mediterranean (Bougiatioti et al., 2014) and some laboratory chamber studies (Lipsky and Robinson, 2006; Robinson et al., 2007; Yee et al., 2013). Particularly, this also means that aged biomass-burning OA (OOA-BB) may be significantly mixed with nitrate in the BB plumes. Healy et al. (2013) also found a similar result in Paris using single-particle mass spectrometer (SP-AMS) and HR-ToF-AMS measurements.

\subsection{Effects of Chemical components on PM pollution}

Figure 7 presents the average contributions of $\mathrm{PM}_{1}$ species and OA components during the summer and autumn harvest, respectively. It is also compared with other sites, including megacities (Mexico City, Paris, Beijing, and Shanghai), and suburban/remote areas (Crete, Jiaxing, and Pearl River delta) (Aiken et al., 2009; Crippa et al., 2013; Huang et al., 2012, 2013; Sun et al., 2012; Bougiatioti et al., 2014). Using the relative contribution of the sum of BBOA and OOA-BB to $\mathrm{OA}$, the harvest season was separated into three time periods, i.e., a low BB (L-BB, 28 and $29 \%$ ) period, medium BB (M-BB, 49 and $38 \%$ ) period, and high BB (H-BB, 93 and $50 \%$ ) period, during the summer and autumn harvest. We also include averages of some meteorological parameters (i.e., RH, $T$, WS, and WD) for the reference, and these averages are shown in Table S2. Compared with other sites including Mexico City, Paris, Crete, Jiaxing, and Pearl River delta (Fig. 7), the BB source shows the largest contribution to aerosol pollution during the $\mathrm{H}-\mathrm{BB}$ both in the summer and autumn harvest in urban Nanjing. In addition, in the absence of BB source the sum of OOA and OOA-BB shows a higher fraction of total OA mass during the harvests in urban Nanjing in comparison with Beijing and Shanghai in China (Fig. 7). This means that the BB source significantly contributes to the SOA pollution in urban Nanjing during harvest seasons.

As shown in Fig. 7, OA is important in PM pollution in the summer and autumn harvest (39 and $41 \%$ ). Furthermore, the average fraction of $\mathrm{BBOA}$ to $\mathrm{OA}$ during the summer har- 

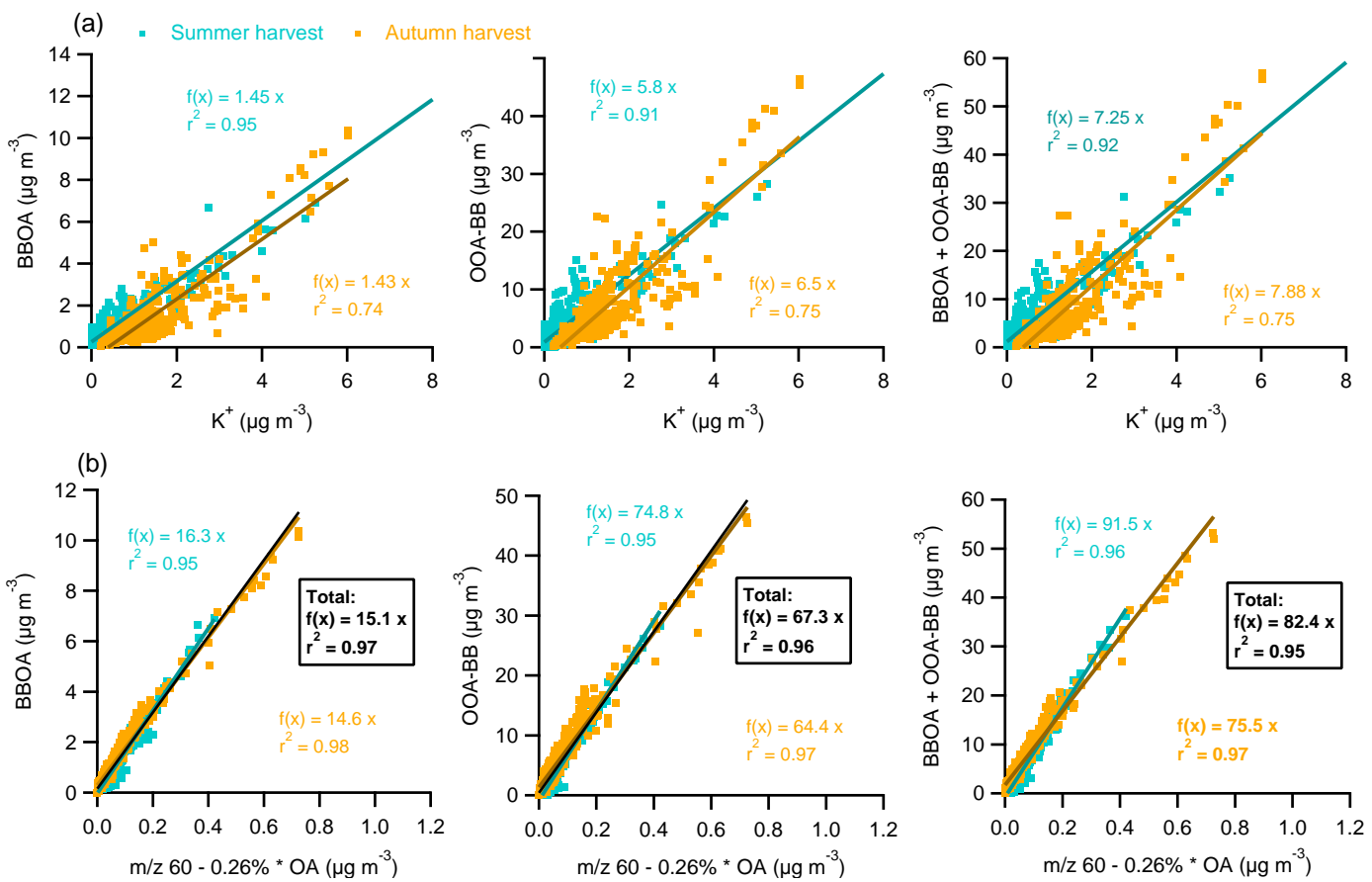

Figure 5. Comparison of biomass-burning-related PMF factors (BBOA and OOA-BB) and biomass-related species: (a) $\mathrm{K}^{+}$and (b) the $\operatorname{ACSM~} m / z, 60$ minus $0.26 \% \times$ OA (applied metric of background $f_{60}=0.26 \%$ of OA is discussed in the Sect. 3.4 of the text) during the summer and autumn harvest.
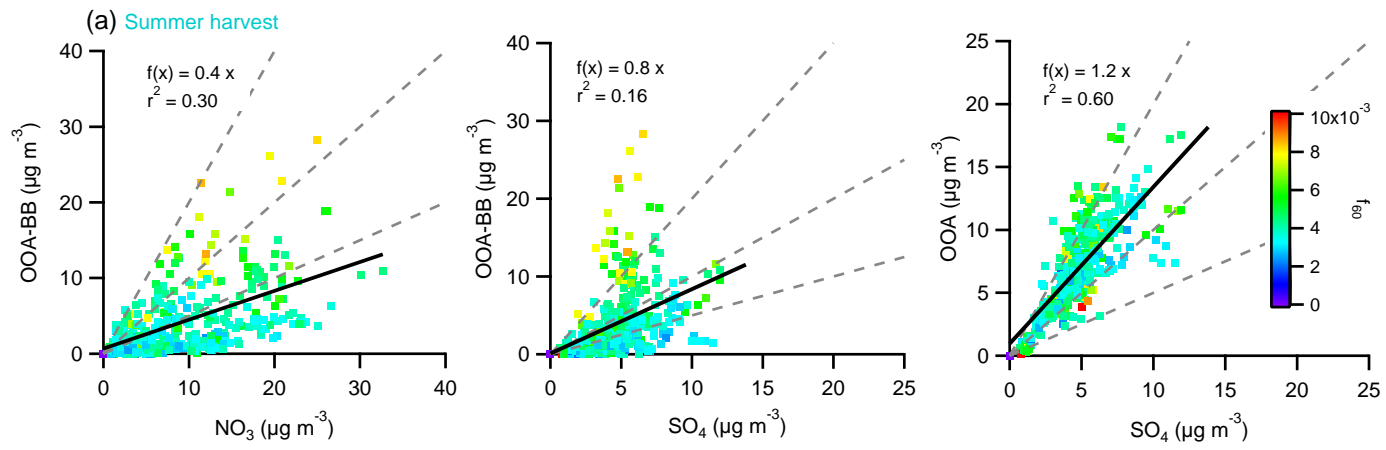

(b) Autumn harvest
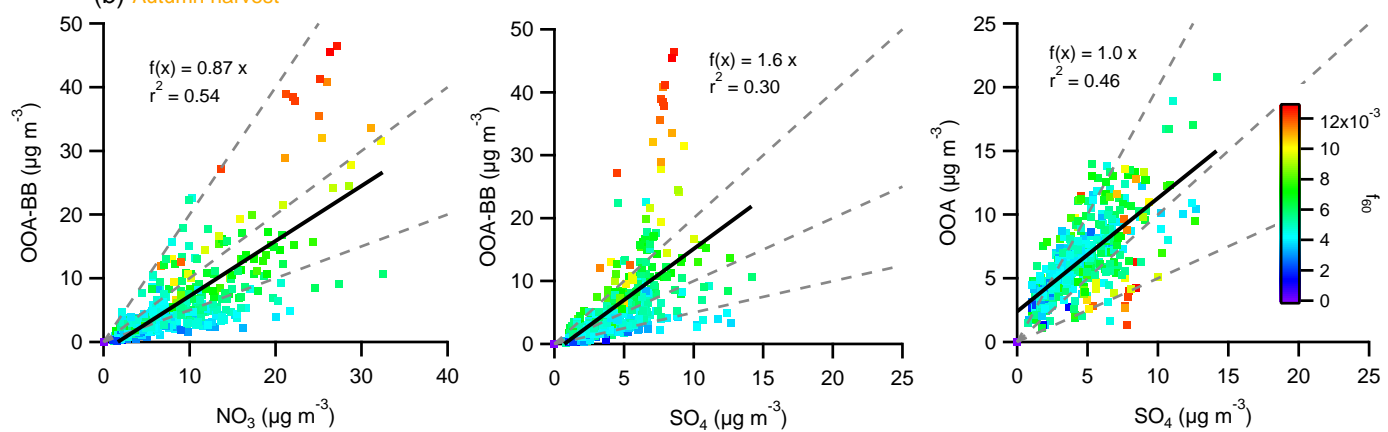

Figure 6. Comparison of two kinds of oxygenated $\mathrm{OA}(\mathrm{OOA}-\mathrm{BB}$ and $\mathrm{OOA})$ and two kinds of secondary inorganic species, i.e., nitrate $\left(\mathrm{NO}_{3}\right)$ and sulfate $\left(\mathrm{SO}_{4}\right)$, during the harvest seasons. Colored by the $f_{60}$ as a biomass-burning marker. The three dashed lines in the plot refer to $2: 1,1: 1$, and $1: 2$ lines, respectively. 

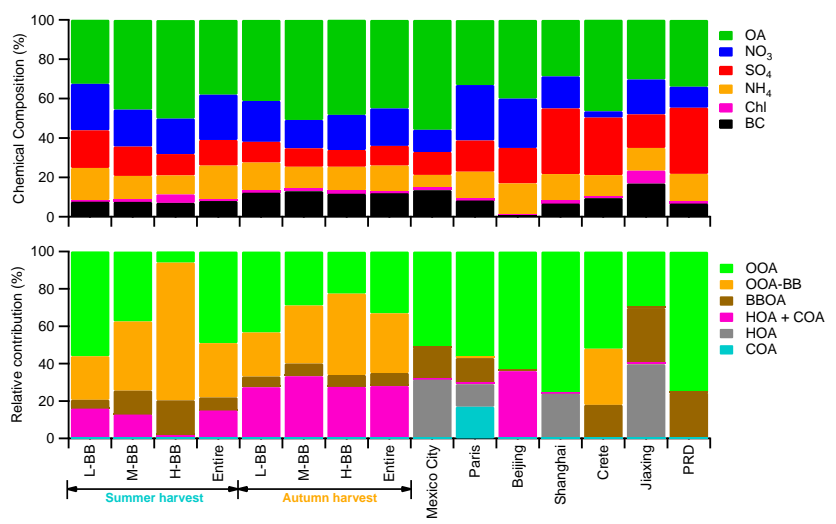

Figure 7. Average relative contributions of $\mathrm{PM}_{1}$ species and $\mathrm{OA}$ components for a low biomass-burning period (L-BB), medium biomass-burning period (M-BB), and high biomass-burning period (H-BB), as well as entire period during the harvest seasons and other sites including megacities (Mexico City, Paris, Beijing, and Shanghai), suburban area (Jiaxing), remote background site (Crete), and PRD (Pearl River delta, China). Note that OOA in this plot includes $\mathrm{OOA}_{2}$-BBOA in Paris.

vest $(7 \%)$ is highly consistent with that in the autumn (7\%), while BC shows a higher fraction during the autumn harvest $(12 \%)$ than that in the summer harvest $(8 \%)$. This is also corresponding to the fraction of $\mathrm{HOA}+\mathrm{COA}$, which shows a higher contribution during the autumn harvest $(28 \%)$ than that in the summer harvest $(15 \%)$. The different boundary layer height and primary sources emission influences on primary pollutants (including $\mathrm{BC}, \mathrm{HOA}$ and $\mathrm{COA}$ ) may be all potential causes of such seasonal differences. On average, the total oxidized fraction of OA (including OOA and OOA-BB) accounts for more than $60 \%$ (78\% for summer and $65 \%$ for autumn harvest), which indicates that regional OOA plays an important role in PM pollution in urban Nanjing during the harvest seasons. As a comparison, OOA-BB shows a higher fraction to $\mathrm{OA}$ in the $\mathrm{H}-\mathrm{BB}$ period than in the L-BB period. The fraction of OOA-BB to OA is higher than the fraction of BBOA during the harvest seasons, even in the H-BB period. These findings indicate that aged BBOA plays a more significant role in PM pollution than BBOA in the BB plumes, particularly in the H-BB period. This is consistent with recent studies (Grieshop et al., 2009; Heringa et al., 2011; Lathem et al., 2013; Yee et al., 2013; Bougiatioti et al., 2014) indicating that the fresh BB-emission OA can be rapidly surpassed by SOA formation within a few hours after its emission.

The secondary inorganic aerosols (including sulfate, nitrate, and ammonium) can be seen in lower fraction in the $\mathrm{H}$ $\mathrm{BB}$ period than in the L-BB period. However, the mass concentrations of sulfate, nitrate, and ammonium are higher in the H-BB period than in the L-BB period (Table S2). Therefore, these findings indicate that the $\mathrm{BB}$ source contributes more to OA than secondary inorganic components. It is interesting that the contribution of nitrate to $\mathrm{PM}_{1}$ is higher than (a) Summer harves

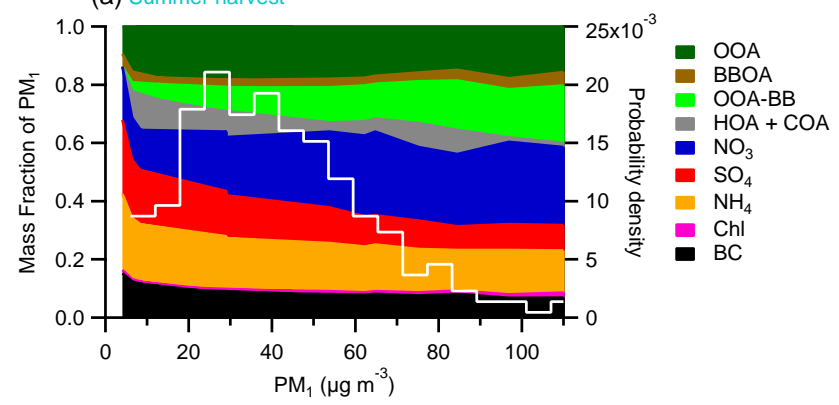

(b) Autumn harvest

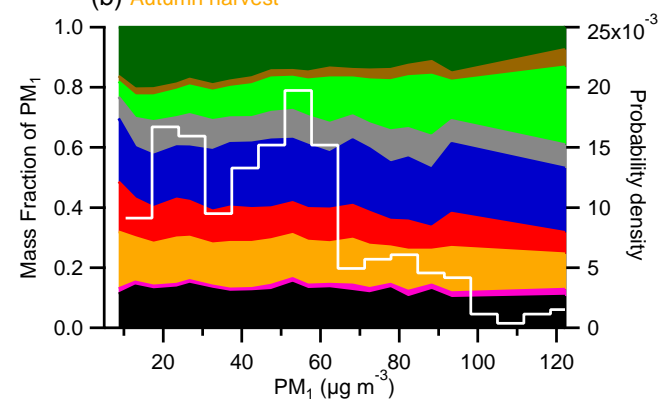

Figure 8. The mass fractions of $\mathrm{PM}_{1}$ species and $\mathrm{OA}$ components as a function of $\mathrm{PM}_{1}$ mass loadings (left), and probability density of $\mathrm{PM}_{1}$ mass loadings (right, with the white lines in the plots) during the summer (a) and autumn (b) harvest, respectively.

the contribution of sulfate in the $\mathrm{H}-\mathrm{BB}$ periods during the two harvest seasons. For example, the average contribution of nitrate to $\mathrm{PM}_{1}$ is $\sim 18 \%$ in the $\mathrm{H}$-BB periods, which is almost two times higher than that of sulfate. However, the contribution of nitrate to $\mathrm{PM}_{1}$ is very similar to the sulfate contribution in the L-BB periods. This all indicates that BB is a much more important source of nitrate, compared to sulfate. Similar results have been observed by Crippa et al. (2013), Healy et al. (2013), and Bougiatioti et al. (2014) during open BB periods.

Figure 8 presents the mass fractions of $\mathrm{PM}_{1}$ species and $\mathrm{OA}$ components as a function of total $\mathrm{PM}_{1}$ mass loadings, as well as the probability density of total $\mathrm{PM}_{1}$ mass loadings during the summer and autumn harvest. Overall, the total OA fraction increases from about $\sim 15$ to $40 \%$ and from $\sim 30$ to $45 \%$ as a function of the $\mathrm{PM}_{1}$ loadings during summer and autumn, respectively. Indeed, OOA-BB and BBOA show a significant increase as a function of the $\mathrm{PM}_{1}$ loadings during the harvest seasons. The contribution of OOA-BB to $\mathrm{PM}_{1}$ increases from $\sim 3(\sim 5 \%)$ to $33 \%$ (26\%) during the summer (autumn) harvest. And the contribution of BBOA increases from $\sim 2(\sim 4 \%)$ to $8 \%(8 \%)$. The results highlight the contribution of OOA-BB arising from BB emissions to $\mathrm{PM}$ pollution in the harvests. During the summer harvest, the $\mathrm{HOA}+\mathrm{COA}$ and $\mathrm{BC}$ mass fractions display a slight decrease, suggesting that local primary sources play an important in the low PM pollution period. In addition, the nitrate 


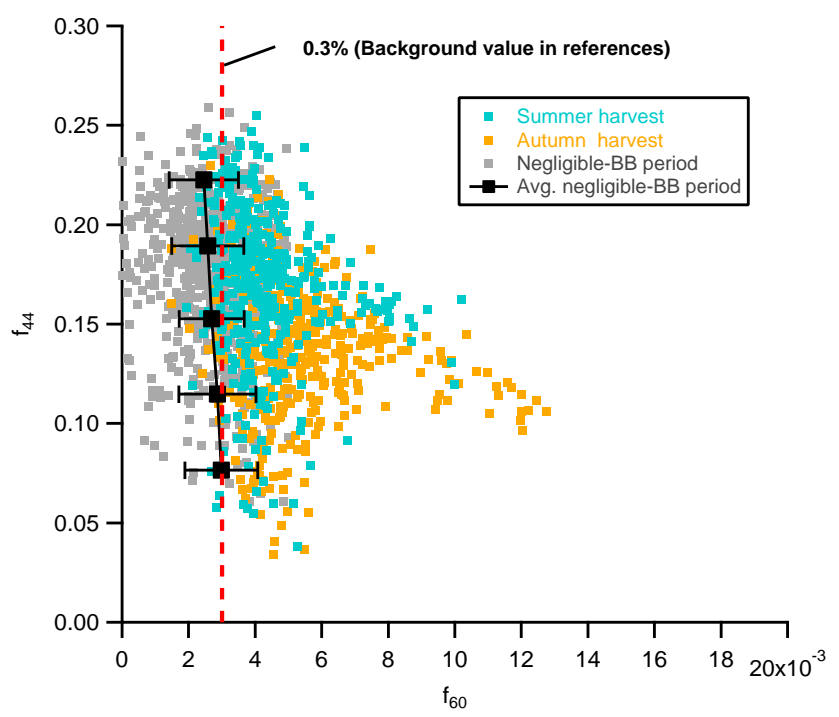

Figure 9. Summary plots showing $f_{44}$ vs. $f_{60}$ for measurements with little or negligible biomass-burning influence. Colored by the summer harvest (blue), autumn harvest (orange), and a little/negligible biomass-burning influence period (gray, 1 to 8 July 2013). Also shown is the average background level of $f_{60}(\sim 0.3 \%$, red dashed line) in other studies from Aiken et al. (2009) and Cubison et al. (2011) for references.

and sulfate contributions show a slight increase and decrease, indicating additional production of nitrate mass during high PM episodes. Note that the mass fraction of OOA shows a slight decrease with the increasing of total $\mathrm{PM}_{1}$ loadings during the autumn harvest. This suggests that OOA mainly contributes to the low PM pollution, and OOA-BB mainly contributes to the high PM pollution. However, the contribution of $\mathrm{HOA}+\mathrm{COA}, \mathrm{BC}$, and the secondary inorganic species to the total $\mathrm{PM}_{1}$ loadings did not show clear PM mass loading dependency, which indicates that the high PM pollution during the autumn harvest may be caused by the synergistic effects of all pollutants.

\subsection{Estimation of BBOA directly from a tracer $(\Delta m / z$ 60)}

The BBOA mass loadings during the harvest seasons were estimated a posteriori using a simple method. As described in previous studies, the parameter $f_{60}$, fraction of $m / z 60$ in total $\mathrm{OA}$, is considered as a marker of fresh/primary BBOA (Alfarra et al., 2007; DeCarlo et al., 2008; Aiken et al., 2009; Cubison et al., 2011). To estimate the real value of the BBOA loadings, the background fraction of $f_{60}(0.26 \pm 0.1 \%)$ during little/negligible BB-influenced periods (non-BB periods) was determined (Fig. 9). Aiken et al. (2009) and Cubison et al. (2011) also obtained a similar background level of $f_{60}(0.3 \pm 0.06 \%)$ for an urban city in Mexico. Therefore, the levoglucosan-like species in ambient BB plumes was estimated with $\Delta m / z 60(\Delta m / z 60$
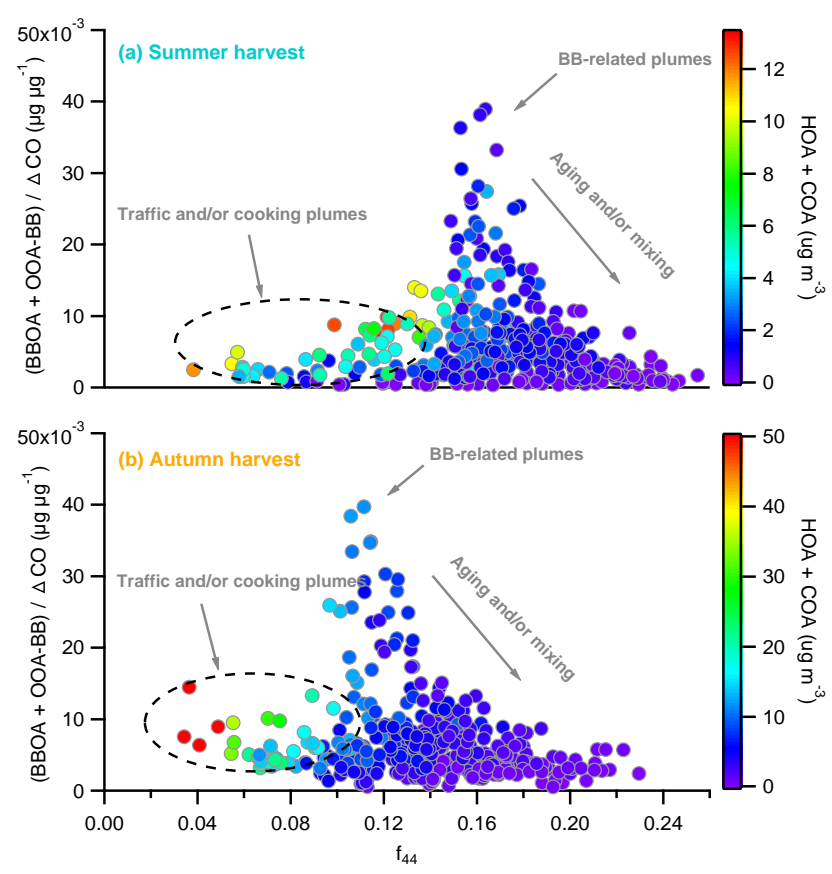

Figure 10. The $(\mathrm{BBOA}+\mathrm{OOA}-\mathrm{BB}) / \Delta \mathrm{CO}$ ratio as a function of $f_{44}$ during the summer and autumn harvest. Colored by the $\mathrm{HOA}+\mathrm{COA}$ mass concentrations for the summer and autumn harvest.

$=m / z 60-$ background value of $\left.f_{60} \times \mathrm{OA}\right)$. As shown in Fig. 5b, the strong correlations $\left(r^{2}=0.95, r^{2}=0.98\right.$, and $\left.r^{2}=0.97\right)$ between the BBOA and $\Delta m / z 60$ with the similar slopes, i.e., 16.3 for summer, 14.6 for autumn, and 15.1 for the total harvest seasons, were observed. The OOA-BB mass loadings also show the high correlations with $\Delta m / z$ $60\left(r^{2}=0.95\right.$ and $\left.r^{2}=0.97\right)$, but with very different slopes (74.8 and 64.4) during the summer and autumn harvest, respectively (Fig. 5b). Aiken et al. (2009) also found that BBOA strongly correlated with $\Delta \mathrm{m} / \mathrm{z} 60$ mass loadings $\left(r^{2}=0.91\right.$, slope $\left.=34\right)$ during the $\mathrm{BB} /$ wood-smoke periods in Mexico City. Furthermore, Lee et al. (2010) obtained a strong relationship between BBOA and $m / z 60$ mass loadings $\left(r^{2}=0.92\right.$, slope $\left.=34.5\right)$ through a wildland fuels fire experiment in the lab. Thus, we reconstructed the time series of $\mathrm{BBOA}$ to compare the relationship between the extracted BBOA by the PMF model (PMF BBOA) and the estimated BBOA. As shown in Fig. S16, an excellent agreement is observed between the identified and reconstructed BBOA concentrations during the total harvest seasons $\left(r^{2}=0.97\right)$. Therefore, the BBOA component during the BB periods in urban Nanjing of the YRD region can be estimated with the equation of $\mathrm{BBOA}=15.1 \times(\mathrm{m} / \mathrm{z} 60-0.26 \% \times \mathrm{OA})$ for the harvest seasons. 

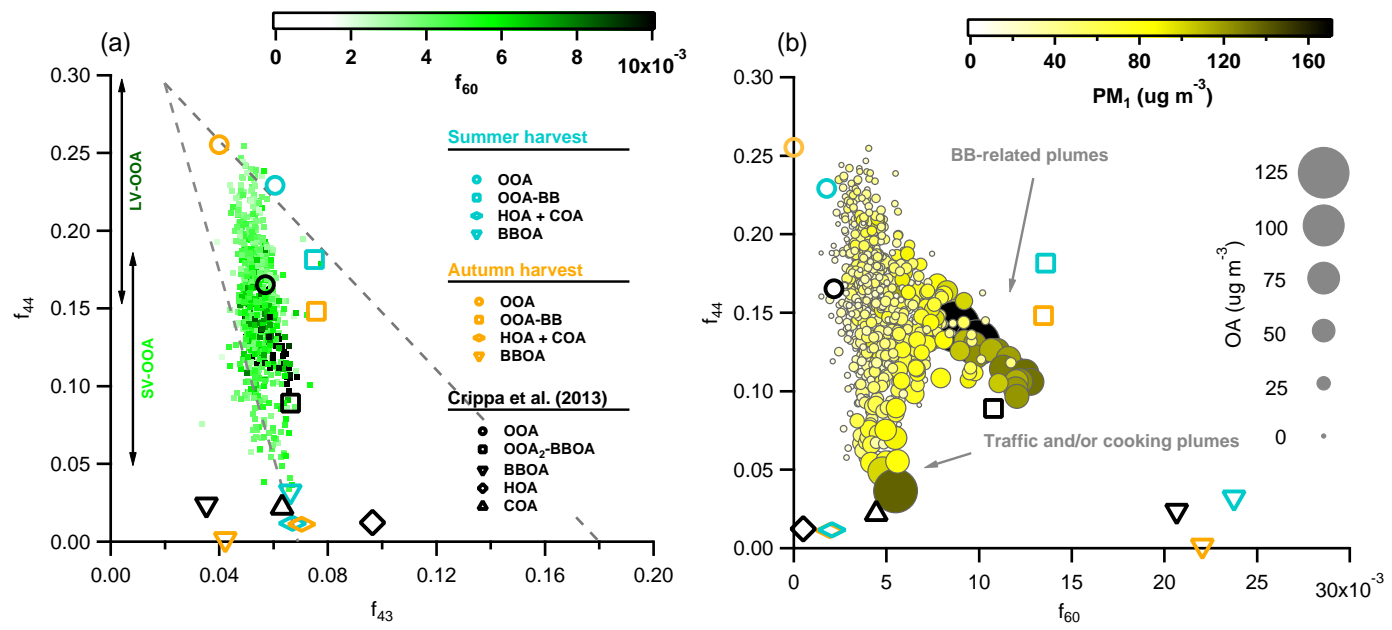

Figure 11. Summary plots showing (a) triangle plot $\left(f_{44}\right.$ vs. $\left.f_{43}\right)$; SV-OOA and LV-OOA indicate semi-volatile OOA and low volatility OOA, respectively. The dots are colored by $f_{60}$ as a biomass-burning marker; (b) $f_{44}$ as a function of $f_{60}\left(f_{44}\right.$ vs. $\left.f_{60}\right)$, colored by the PM mass concentration and sized by the OA loadings.

\subsection{Evaluation of $\mathrm{OA}$}

To further investigate the probable importance of the aging and/or mixing processes of $\mathrm{BB}$ plumes, the total $\mathrm{BB}$ related $\mathrm{OA}(\mathrm{BBOA}+\mathrm{OOA}-\mathrm{BB})$ to $\triangle \mathrm{CO}$ ratio as a function of the $f_{44}$ during the summer and autumn harvest is shown in Fig. 10. The CO background is determined as $14.9 \mu \mathrm{g} \mathrm{m}^{-3}$ for summer harvest and $17.9 \mu \mathrm{g} \mathrm{m}^{-3}$ for autumn harvest based on an average of the lowest $5 \% \mathrm{CO}$ during two plumes (Takegawa et al., 2006). The ratio of BBOA + OOA$\mathrm{BB}$ to $\triangle \mathrm{CO}$ can remove the effect of dilution in the atmosphere (de Gouw 2005; Dunlea et al., 2009; DeCarlo et al., 2008, 2010). As discussed in de Gouw et al. (2005), Aiken et al. (2008), Jimenez et al. (2009), and Ng et al. (2010), the $f_{44}$ can be considered as indicator of atmospheric aging due to photochemical aging processes leading to the increasing of $f_{44}$ in the atmosphere. Overall, the (BBOA + OOA$\mathrm{BB}) / \triangle \mathrm{CO}$ ratio shows an obvious reduction with increasing $f_{44}$ values during the summer and autumn harvest in the absence of traffic and cooking-like plumes. This is likely due to a synergistic effect of the rapid formation of OOA from $\mathrm{BB}$ plumes and the mixing of BBOA with regional OOA and/or CO. Similar results have been found by DeCarlo et al. (2010), from aircraft measurements during MILAGRO in Mexico City and the central Mexican plateau.

Figure 11a depicts the evolution process of OA with the $f_{44}$ vs. $f_{43}$ space during two harvest seasons. The BBOA and HOA + COA show similar low oxidative properties with varying $f_{43}$, which are located at the bottom left of the triangular region during the summer and autumn harvest. With the aging process in the atmosphere, OA clusters within a welldefined triangular region and shows more similar oxidative properties to OOA-BB and/or OOA (Fig. 11a). This implies that OOA-BB and/or BBOA might be further oxidized, and might be transformed into highly oxidized OOA.

Furthermore, the formation and transformation of primary and secondary BBOA during BB periods can be described by $f_{44}$ vs. $f_{60}$ plot (Cubison et al., 2011). In the $f_{44}$ vs. $f_{60}$ space of Fig. 11b, OA shows a trend toward higher $f_{44}$ and lower $f_{60}$ values with the aging of $\mathrm{BB}$ plumes, appearing into the low volatility OOA (LV-OOA) range. This is very consistent with previous reports in aircraft and laboratory studies (Cubison et al., 2011) with a similar trend. In a smog chamber experiment, Grieshop et al. (2009) also found that the relative contribution at $m / z 44$ and $m / z 60$ rapidly increases and decreases, respectively, during the aging process, which presents the characteristics of fresh and aged BBOA.

\subsection{Impacts of various source regions on the PM pollution}

Figure 12 presents the BTs clusters of air masses at $500 \mathrm{~m}$ arrival height above ground level at intervals of $2 \mathrm{~h}(00: 00$, 02:00, 04:00, etc.) starting at CST using the HYSPLIT model (Draxler and Rolph, 2003) in Nanjing $\left(118^{\circ} 46^{\prime} \mathrm{N}, 32^{\circ} 05^{\prime} \mathrm{E}\right)$. The corresponding BTs can be broadly classified into four principal clusters of air masses based on the spatial distributions during the summer and autumn harvests, i.e., northeasterly (NE) BTs, easterly marine (EM) BTs, southeasterly marine (SEM) BTs, and southwesterly continental (SWC) for the summer harvest; northerly continental (NC) BTs, northeasterly marine (NEM) BTs, easterly marine (EM) BTs and southerly continental (SC) for the autumn harvest. The air masses in Nanjing in this study were mainly from the SEM BTs (accounting for $57.4 \%$ of all the BTs) during the summer harvest, while predominantly from the NC and EM BTs 

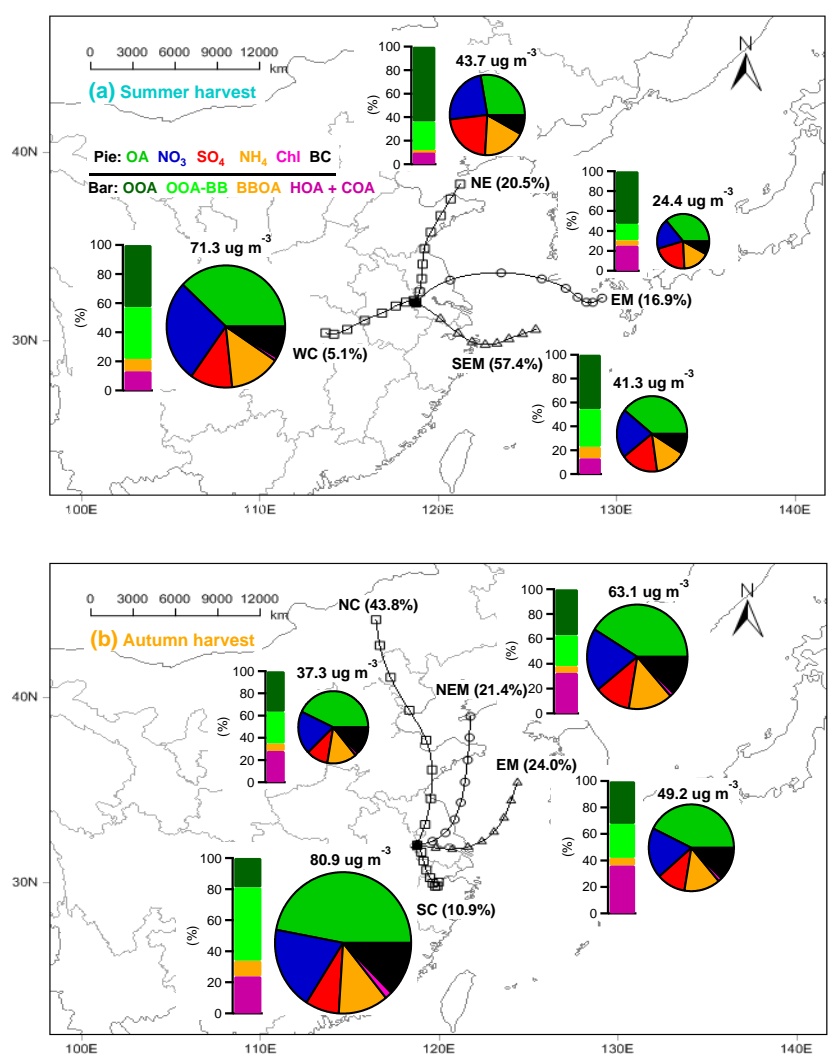

Figure 12. Average composition of $\mathrm{PM}_{1}$ (pie charts) and OA factors (bar charts) for each cluster. The four clusters are (a) northeasterly (NE) back trajectories (BTs), easterly marine (EM) BTs, southeasterly marine (SEM) BTs, and westerly continental (WC) during the summer harvest; and (b) northerly continental (NC) BTs, northeasterly marine (NEM) BTs, easterly marine (EM) BTs, and southerly continental (SC) during the autumn harvest. The markers on the trajectories indicate $6 \mathrm{~h}$ interval.

(at frequencies of 43.8 and $24 \%$, respectively) during the autumn harvest (Fig. 12 and Table S3).

The average $\mathrm{PM}_{1}$ loadings are the highest $\left(71.3 \mu \mathrm{g} \mathrm{m}^{-3}\right)$ for the westerly continental (WC) BTs, which is almost two times higher than that of the lowest $\left(24.4 \mu \mathrm{g} \mathrm{m}^{-3}\right)$ for the EM BTs during the summer harvest. This suggests that the longrange transported pollutants from southwestern areas can cause the high PM pollution in the YRD region during the summer harvest. Similarly, the highest average concentration of $\mathrm{PM}_{1}\left(80.9 \mu \mathrm{g} \mathrm{m}^{-3}\right)$ is associated with the continentalrelated air masses during the autumn harvest. Therefore, source regions related to the fire locations (Fig. S1) are of utmost importance to the high air pollution in the YRD region during the harvest seasons.

The $\mathrm{PM}_{1}$ chemical compositions show also significantly different fraction among the four clusters during the summer and autumn harvest, which might be associated with the different source regions of air pollution. The lowest $\mathrm{PM}_{1}$ loadings are associated with the EM BTs, but with the high contribution of $\mathrm{HOA}+\mathrm{COA}$ during the summer harvest (Fig. 12a). This suggests that the local sources play a key role in controlling aerosol pollution during relatively clean periods in the summer harvest. For the NE BTs, the OOA, nitrate, and sulfate provide high fractions of the total $\mathrm{PM}_{1}$ mass, suggesting that regional pollution plays a key role in controlling PM pollution. With regards to the marine-related air masses, $\mathrm{PM}_{1}$ loadings associated with the NEM and NE BTs are higher in the autumn harvest than in the summer harvest (Fig. 12b), which may be due to the fact that high local POA contributes to PM pollution. This suggests that local sources play a more important role in the aerosol pollution in the autumn harvest than in the summer harvest. Compared with other clusters during the autumn harvest, the BB-related components (e.g., BBOA, OOA-BB, and chloride) contribute the highest fractions to the $\mathrm{PM}_{1}$ mass in air masses originating from the SC BTs, indicating that BB plumes can contribute to the highest, heaviest PM pollution during the autumn harvest. Apart from the high contributions of nitrate and OOA, HOA + COA also accounted for a higher fraction to $\mathrm{PM}_{1}$ mass in the NEM and EM BTs than in other clusters during the autumn harvest. In addition, the $\mathrm{PM}_{1}$ components show the lowest concentrations for the NC BTs, compared to the other clusters during the autumn harvest. When removing the mass concentrations of BB-related OA (BBOA and OOA-BB), the mean concentration of $\mathrm{PM}_{1}\left(31.6 \mu \mathrm{g} \mathrm{m}^{-3}\right)$ for the NC BTs is corresponding to a result $\left(28.7 \mu \mathrm{g} \mathrm{m}^{-3}\right)$ for a similar cluster during a non-BB period (Huang et al., 2012).

\section{Conclusions}

The characteristics, sources, and evolution of atmospheric $\mathrm{PM}_{1}$ species in urban Nanjing, the YRD region of China, were investigated using an Aerodyne ACSM during the two harvest seasons, namely, the summer wheat harvest (June 1 to 15, 2013) and the autumn rice harvest (October 15 to 30, 2013). The $\mathrm{PM}_{1}$ species show a similar contribution, which on average account for $39 \%(41 \%) \mathrm{OA}, 23 \%(20 \%)$ nitrate, $16 \%(14 \%)$ ammonium, $12 \%(11 \%)$ sulfate, $8 \%(13 \%)$ $\mathrm{BC}$, and $1 \%(1 \%)$ chloride during the summer (autumn) harvest. Secondary inorganic species, i.e., nitrate, sulfate, and ammonium, show highly similar diurnal patterns between the summer and autumn harvest, namely, similar chemical processing and physical processes (e.g., gas-particle partitioning). In particular, OA, chloride, and $\mathrm{BC}$ present higher concentrations in the diurnal cycles during the autumn harvest than during the summer harvest, due to larger impacts of BB and/or local primary emissions during the autumn harvest.

PMF analysis was performed on the ACSM OA mass spectra to investigate organic source apportionment during the two harvests. Four OA components were resolved including two POA factors associated with traffic and cooking $(\mathrm{HOA}+\mathrm{COA})$ and biomass-burning $\mathrm{OA}(\mathrm{BBOA})$ emissions and two secondary factors associated with regional 
and highly oxidized OOA and less oxidized BB-like OA (OOA-BB). Apart from HOA + COA, BBOA, and OOA-BB also present pronounced diurnal cycles during the harvests, with the highest concentrations occurring at night due to the nighttime BB plumes over urban Nanjing. This suggests that BBOA components may be quickly oxidized to OOA-BB during the nighttime with the high $\mathrm{RH}$ and low $T$ conditions. The diurnal profiles of OOA are similar to that of sulfate with relatively flat variations, reflecting their regional origin. $\mathrm{OA}$ was dominated by secondary organics (OOA and OOA-BB) with the fraction more than $60 \%$ to total OA mass. POA shows a lower contribution to OA during the summer (autumn) harvest, traffic and cooking $15 \%(28 \%)$, and BB $7 \%$ $(7 \%)$ emissions. The background level of $f_{60}(0.26 \pm 0.1 \%)$ was determined using the $f_{44}$ vs. $f_{60}$ space during the nonBB periods (in July). Thus, we suggest a simpler method for estimating the fresh BBOA loadings based on the equation of $\mathrm{BBOA}=15.1 \times(m / z 60-0.26 \% \times \mathrm{OA})$ during the harvests. The (BBOA + OOA-BB) $/ \triangle \mathrm{CO}$ ratios decrease with the increasing of the $f_{44}$, suggesting that BBOA components may be oxidized to more aged and less volatile OOA, e.g., LVOOA during the aging process. Air mass trajectory analysis indicates that the high $\mathrm{PM}$ pollution is mainly contributed by nitrate, BBOA, and OOA-BB, which is associated with air masses originating from the western (summer harvest) and southern (autumn harvest) areas.

\section{The Supplement related to this article is available online at doi:10.5194/acp-15-1331-2015-supplement.}

Acknowledgements. This work was funded by the Natural Science Key Research of Jiangsu Province High Education (11KJA170002), the Foundation Research Project of Jiangsu Province (BK2012884, BK20140987), the Project Funded by the Jiangsu Province Science and Technology Support Program (BE2012771), the Environmental Monitoring Scientific Research Foundation of Jiangsu Province (1016), and the National Natural Science Foundation of China (21407080). We are very grateful for the help and support from Douglas R. Worsnop and John T. Jayne (Aerodyne Research Inc.) in the ACSM measurements. We also would like to thank P. Chen (Handix LLC) and W. Li (South Coast Air Quality Management District) for their constructive suggestions in improving the contents. We thank the reviewers for their valuable comments on the manuscript.

Edited by: W. Maenhaut

\section{References}

Aiken, A. C., Decarlo, P. F., Kroll, J. H., Worsnop, D. R., Huffman, J. A., Docherty, K. S., Ulbrich, I. M., Mohr, C., Kimmel, J. R., Sueper, D., Sun, Y., Zhang, Q., Trimborn, A., Northway, M., Ziemann, P. J., Canagaratna, M. R., Onasch, T. B., Alfarra, M. R., Prevot, A. S. H., Dommen, J., Duplissy, J., Metzger, A., Baltensperger, U., and Jimenez, J. L.: O/C and OM/OC ratios of primary, secondary, and ambient organic aerosols with high-resolution time-of-flight aerosol mass spectrometry, Environ. Sci. Technol., 42, 4478-4485, 2008.

Aiken, A. C., Salcedo, D., Cubison, M. J., Huffman, J. A., DeCarlo, P. F., Ulbrich, I. M., Docherty, K. S., Sueper, D., Kimmel, J. R., Worsnop, D. R., Trimborn, A., Northway, M., Stone, E. A., Schauer, J. J., Volkamer, R. M., Fortner, E., de Foy, B., Wang, J., Laskin, A., Shutthanandan, V., Zheng, J., Zhang, R., Gaffney, J., Marley, N. A., Paredes-Miranda, G., Arnott, W. P., Molina, L. T., Sosa, G., and Jimenez, J. L.: Mexico City aerosol analysis during MILAGRO using high resolution aerosol mass spectrometry at the urban supersite (T0) - Part 1: Fine particle composition and organic source apportionment, Atmos. Chem. Phys., 9, 6633-6653, doi:10.5194/acp-9-6633-2009, 2009.

Aiken, A. C., de Foy, B., Wiedinmyer, C., DeCarlo, P. F., Ulbrich, I. M., Wehrli, M. N., Szidat, S., Prévôt, A. S. H., Noda, J., Wacker, L., Volkamer, R., Fortner, E., Wang, J., Laskin, A., Shutthanandan, V., Zheng, J., Zhang, R., ParedesMiranda, G., Arnott, W. P., Molina, L. T., Sosa, G., Querol, X., and Jimenez, J. L.: Mexico city aerosol analysis during MILAGRO using high resolution aerosol mass spectrometry at the urban supersite (T0) - Part 2: Analysis of the biomass burning contribution and the non-fossil carbon fraction, Atmos. Chem. Phys., 10, 5315-5341, doi:10.5194/acp-10-5315-2010, 2010.

Alfarra, M. R., Prévôt, A. S. H., Szidat, S., Sandradewi, J., Weimer, S., Schreiber, D., Mohr, M., and Baltensperger, U.: Identification of the mass spectral signature of organic aerosols from wood burning emissions, Environ. Sci Technol., 41, 5770-5777, 2007.

Allan, J. D., Bower, K. N., Coe, H., Boudries, H., Jayne, J. T., Canagaratna, M. R., Millet, D. B., Goldstein, A. H., Quinn, P. K., Weber, R. J., W. D. R.: Submicron aerosol composition at Trinidad Head, California, during ITCT 2K2: Its relationship with gas phase volatile organic carbon and assessment of instrument performance, J. Geophys. Res., 109, D23S24, doi:10.1029/2003JD004208, 2004.

Allan, J. D., Williams, P. I., Morgan, W. T., Martin, C. L., Flynn, M. J., Lee, J., Nemitz, E., Phillips, G. J., Gallagher, M. W., and Coe, H.: Contributions from transport, solid fuel burning and cooking to primary organic aerosols in two UK cities, Atmos. Chem. Phys., 10, 647-668, doi:10.5194/acp-10-647-2010, 2010.

Andreae, M. O., and Merlet, P.: Emission of trace gases and aerosols from biomass burning, Global Biogeochem. Cycles, 15, 955966, 2001.

Bougiatioti, A., Stavroulas, I., Kostenidou, E., Zarmpas, P., Theodosi, C., Kouvarakis, G., Canonaco, F., Prévôt, A. S. H., Nenes, A., Pandis, S. N., and Mihalopoulos, N.: Processing of biomassburning aerosol in the eastern Mediterranean during summertime, Atmos. Chem. Phys., 14, 4793-4807, doi:10.5194/acp-144793-2014, 2014.

Canagaratna, M., Jayne, J., Jimenez, J. L., Allan, J. A., Alfarra, R., Zhang, Q., Onasch, T., Drewnick, F., Coe, H., Middlebrook, 
A., Delia, A., Williams, L., Trimborn, A., Northway, M., Kolb, C., Davidovits, P., and Worsnop, D.: Chemical and microphysical characterization of aerosols via Aerosol Mass Spectrometry, Mass Spectrom. Rev., 26, 185-222, 2007.

Canonaco, F., Crippa, M., Slowik, J. G., Baltensperger, U., and Prévôt, A. S. H.: SoFi, an IGOR-based interface for the efficient use of the generalized multilinear engine (ME-2) for the source apportionment: ME-2 application to aerosol mass spectrometer data, Atmos. Meas. Tech., 6, 3649-3661, doi:10.5194/amt6-3649-2013, 2013.

Cheng, Y., Engling, G., He, K.-B., Duan, F.-K., Ma, Y.-L., Du, Z.Y., Liu, J.-M., Zheng, M., and Weber, R. J.: Biomass burning contribution to Beijing aerosol, Atmos. Chem. Phys., 13, 77657781, doi:10.5194/acp-13-7765-2013, 2013.

Crippa, M., DeCarlo, P. F., Slowik, J. G., Mohr, C., Heringa, M. F., Chirico, R., Poulain, L., Freutel, F., Sciare, J., Cozic, J., Di Marco, C. F., Elsasser, M., Nicolas, J. B., Marchand, N., Abidi, E., Wiedensohler, A., Drewnick, F., Schneider, J., Borrmann, S., Nemitz, E., Zimmermann, R., Jaffrezo, J.-L., Prévôt, A. S. H., and Baltensperger, U.: Wintertime aerosol chemical composition and source apportionment of the organic fraction in the metropolitan area of Paris, Atmos. Chem. Phys., 13, 961-981, doi:10.5194/acp-13-961-2013, 2013.

Crippa, M., Canonaco, F., Lanz, V. A., Äijälä, M., Allan, J. D., Carbone, S., Capes, G., Ceburnis, D., Dall'Osto, M., Day, D. A., DeCarlo, P. F., Ehn, M., Eriksson, A., Freney, E., Hildebrandt Ruiz, L., Hillamo, R., Jimenez, J. L., Junninen, H., Kiendler-Scharr, A., Kortelainen, A.-M., Kulmala, M., Laaksonen, A., Mensah, A. A., Mohr, C., Nemitz, E., O’Dowd, C., Ovadnevaite, J., Pandis, S. N., Petäjä, T., Poulain, L., Saarikoski, S., Sellegri, K., Swietlicki, E., Tiitta, P., Worsnop, D. R., Baltensperger, U., and Prévôt, A. S. H.: Organic aerosol components derived from 25 AMS data sets across Europe using a consistent ME-2 based source apportionment approach, Atmos. Chem. Phys., 14, 61596176, doi:10.5194/acp-14-6159-2014, 2014.

Cubison, M. J., Ortega, A. M., Hayes, P. L., Farmer, D. K., Day, D., Lechner, M. J., Brune, W. H., Apel, E., Diskin, G. S., Fisher, J. A., Fuelberg, H. E., Hecobian, A., Knapp, D. J., Mikoviny, T., Riemer, D., Sachse, G. W., Sessions, W., Weber, R. J., Weinheimer, A. J., Wisthaler, A., and Jimenez, J. L.: Effects of aging on organic aerosol from open biomass burning smoke in aircraft and laboratory studies, Atmos. Chem. Phys., 11, 12049-12064, doi:10.5194/acp-11-12049-2011, 2011.

DeCarlo, P. F., Dunlea, E. J., Kimmel, J. R., Aiken, A. C., Sueper, D., Crounse, J., Wennberg, P. O., Emmons, L., Shinozuka, Y., Clarke, A., Zhou, J., Tomlinson, J., Collins, D. R., Knapp, D., Weinheimer, A. J., Montzka, D. D., Campos, T., and Jimenez, J. L.: Fast airborne aerosol size and chemistry measurements above Mexico City and Central Mexico during the MILAGRO campaign, Atmos. Chem. Phys., 8, 4027-4048, doi:10.5194/acp-8-4027-2008, 2008.

DeCarlo, P. F., Ulbrich, I. M., Crounse, J., de Foy, B., Dunlea, E. J., Aiken, A. C., Knapp, D., Weinheimer, A. J., Campos, T., Wennberg, P. O., and Jimenez, J. L.: Investigation of the sources and processing of organic aerosol over the Central Mexican Plateau from aircraft measurements during MILAGRO, Atmos. Chem. Phys., 10, 5257-5280, doi:10.5194/acp-10-52572010, 2010. de Gouw, J. A., Middlebrook, A. M., Warneke, C., Goldan, P. D., Kuster, W. C., Roberts, J. M., Fehsenfeld, F. C., Worsnop, D. R., Canagaratna, M. R., Pszenny, A. A. P., Keene, W. C., Marchewka, M., Bertman, S. B., and Bates, T. S.: Budget of organic carbon in a polluted atmosphere: Results from the New England Air Quality Study in 2002, J. Geophys. Res. Atmos., 110, D16305, 2005.

Ding, A. J., Fu, C. B., Yang, X. Q., Sun, J. N., Petäjä, T., Kerminen, V.-M., Wang, T., Xie, Y., Herrmann, E., Zheng, L. F., Nie, W., Liu, Q., Wei, X. L., and Kulmala, M.: Intense atmospheric pollution modifies weather: a case of mixed biomass burning with fossil fuel combustion pollution in eastern China Atmos. Chem. Phys., 13, 10545-10554, doi:10.5194/acp-1310545-2013, 2013.

Draxler, R. R., Rolph, G. D.: HYSPLIT (HYbrid Single-Particle Lagrangian Integrated Trajectory) Model Access via NOAA ARL READY Website. NOAA Air Resources Laboratory, Silver Spring, MD. http://www.arl.noaa.gov/ready/hysplit4.html, 2003.

Du, H. H., Kong, L.D., Cheng, T.T., Chen, J.M., Du, J.F., Li, L., Xia, X.G., Leng, C.P., Huang, G. H.: Insights into summertime haze pollution events over Shanghai based on online water-soluble ionic composition of aerosols, Atmos. Environ., 45, 5131-5137, 2011.

Dunlea, E. J., DeCarlo, P. F., Aiken, A. C., Kimmel, J. R., Peltier, R. E., Weber, R. J., Tomlinson, J., Collins, D. R., Shinozuka, Y., McNaughton, C. S., Howell, S. G., Clarke, A. D., Emmons, L. K., Apel, E. C., Pfister, G. G., van Donkelaar, A., Martin, R. V., Millet, D. B., Heald, C. L., and Jimenez, J. L.: Evolution of Asian aerosols during transpacific transport in INTEX-B, Atmos. Chem. Phys., 9, 7257-7287, doi:10.5194/acp-9-7257-2009, 2009.

Ge, W. Z., Chen, R. J., Song, W. M., and Kan, H. D.: Daily visibility and hospital admission in Shanghai, China, Biomed Environ. Sci., 24, 117-121, 2011.

Gilardoni, S., Liu, S., Takahama, S., Russell, L. M., Allan, J. D., Steinbrecher, R., Jimenez, J. L., De Carlo, P. F., Dunlea, E. J., and Baumgardner, D.: Characterization of organic ambient aerosol during MIRAGE 2006 on three platforms, Atmos. Chem. Phys., 9, 5417-5432, doi:10.5194/acp-9-5417-2009, 2009.

Grieshop, A. P., Donahue, N. M., and Robinson, A. L.: Laboratory investigation of photochemical oxidation of organic aerosol from wood fires 2: analysis of aerosol mass spectrometer data, Atmos. Chem. Phys., 9, 2227-2240, doi:10.5194/acp-9-2227-2009, 2009.

He, L.-Y., Lin, Y., Huang, X.-F., Guo, S., Xue, L., Su, Q., Hu, M., Luan, S.-J., and Zhang, Y.-H.: Characterization of highresolution aerosol mass spectra of primary organic aerosol emissions from Chinese cooking and biomass burning, Atmos. Chem Phys., 10, 11535-11543, doi:10.5194/acp-10-11535-2010, 2010.

Healy, R. M., Sciare, J., Poulain, L., Crippa, M., Wiedensohler, A., Prévôt, A. S. H., Baltensperger, U., Sarda-Estève, R., McGuire, M. L., Jeong, C.-H., McGillicuddy, E., O’Connor, I. P., Sodeau, J. R., Evans, G. J., and Wenger, J. C.: Quantitative determination of carbonaceous particle mixing state in Paris using single-particle mass spectrometer and aerosol mass spectrometer measurements, Atmos. Chem. Phys., 13, 9479-9496, doi:10.5194/acp13-9479-2013, 2013.

Heringa, M. F., DeCarlo, P. F., Chirico, R., Tritscher, T., Dommen, J., Weingartner, E., Richter, R., Wehrle, G., Prévôt, A. S. H., 
and Baltensperger, U.: Investigations of primary and secondary particulate matter of different wood combustion appliances with a high-resolution time-of-flight aerosol mass spectrometer, Atmos. Chem. Phys., 11, 5945-5957, doi:10.5194/acp-11-59452011, 2011.

Hu, W. W., Hu, M., Yuan, B., Jimenez, J. L., Tang, Q., Peng, J. F., Hu, W., Shao, M., Wang, M., Zeng, L. M., Wu, Y. S., Gong, Z. H., Huang, X. F., and He, L. Y.: Insights on organic aerosol aging and the influence of coal combustion at a regional receptor site of central eastern China, Atmos. Chem. Phys., 13, 10095-10112, doi:10.5194/acp-13-10095-2013, 2013.

Huang, X.-F., He, L.-Y., Hu, M., Canagaratna, M. R., Sun, Y., Zhang, Q., Zhu, T., Xue, L., Zeng, L.-W., Liu, X.-G., Zhang, Y.-H., Jayne, J. T., Ng, N. L., and Worsnop, D. R.: Highly time-resolved chemical characterization of atmospheric submicron particles during 2008 Beijing Olympic Games using an Aerodyne High-Resolution Aerosol Mass Spectrometer, Atmos. Chem. Phys., 10, 8933-8945, doi:10.5194/acp-10-8933-2010, 2010.

Huang, X.-F., He, L.-Y., Hu, M., Canagaratna, M. R., Kroll, J. H., Ng, N. L., Zhang, Y.-H., Lin, Y., Xue, L., Sun, T.-L., Liu, X.-G., Shao, M., Jayne, J. T., and Worsnop, D. R.: Characterization of submicron aerosols at a rural site in Pearl River Delta of China using an Aerodyne High-Resolution Aerosol Mass Spectrometer, Atmos. Chem. Phys., 11, 1865-1877, doi:10.5194/acp-11-18652011, 2011.

Huang, X.-F., He, L.-Y., Xue, L., Sun, T.-L., Zeng, L.-W., Gong, Z.-H., Hu, M., and Zhu, T.: Highly time-resolved chemical characterization of atmospheric fine particles during 2010 Shanghai World Expo, Atmos. Chem. Phys., 12, 4897-4907, doi:10.5194/acp-12-4897-2012, 2012.

Huang, X.-F., Xue, L., Tian, D.-X., Shao, W.-W., Sun, T.-L., Gong, Z.-H., Ju, W.-W., Jiang, B., Hu, M., and He, L.-Y.: Highly timeresolved carbonaceous aerosol characterization in Yangtze River Delta of China: Composition, mixing state and secondary formation, Atmos. Environ., 64, 200-207, 2013.

Huffman, J. A., Docherty, K. S., Aiken, A. C., Cubison, M. J., Ulbrich, I. M., DeCarlo, P. F., Sueper, D., Jayne, J. T., Worsnop, D. R., Ziemann, P. J., and Jimenez, J. L.: Chemically-resolved aerosol volatility measurements from two megacity field studies, Atmos. Chem. Phys., 9, 7161-7182, doi:10.5194/acp-9-71612009, 2009.

Jimenez, J. L., Canagaratna, M. R., Donahue, N. M., Prévôt, A. S. H., Zhang, Q., Kroll, J. H., DeCarlo, P. F., Allan, J. D., Coe, H., Ng, N. L., Aiken, A. C., Docherty, K. S., Ulbrich, I. M., Grieshop, A. P., Robinson, A. L., Duplissy, J., Smith, J. D., Wilson, K. R., Lanz, V. A., Hueglin, C., Sun, Y. L., Tian, J., Laaksonen, A., Raatikainen, T., Rautiainen, J., Vaattovaara, P., Ehn, M., Kulmala, M., Tomlinson, J. M., Collins, D. R., Cubison, M. J., E, Dunlea, J., Huffman, J. A., Onasch, T. B., Alfarra, M. R., Williams, P. I., Bower, K., Kondo, Y., Schneider, J., Drewnick, F., Borrmann, S., Weimer, S., Demerjian, K., Salcedo, D., Cottrell, L., Griffin, R., Takami, A., Miyoshi, T., Hatakeyama, S., Shimono, A., Sun, J. Y., Zhang, Y. M., Dzepina, K., Kimmel, J. R., Sueper, D., Jayne, J. T., Herndon, S. C., Trimborn, A. M., Williams, L. R., Wood, E. C., Middlebrook, A. M., Kolb, C. E., Baltensperger, U., and Worsnop, D. R.: Evolution of organic aerosols in the atmosphere, Science, 326, 1525-1529, 2009.
Justice, C. O., Giglio, L., Korontzi, S., Owens, J., Morisette, J.T., Roy, D., Descloitres, J., Alleaume, S., Petitcolin, F., Kaufman, Y.: The MODIS fire products, Remote Sens. Environ., 83, 244262, 2002.

Kaufman, Y. J., Tanre, D., and Boucher, O.: A satellite view of aerosols in the climate system, Nature, 419: 215-23, 2002.

Kaufman, Y. J., Ichoku, C., Giglio, L., Korontzi, S., Chu, D. A., Hao, W. M., Li R. R., Justice, C. O.: Fire and smoke observed from the Earth Observing System MODIS instrument-products, validation, and operational use, Int. J. Remote Sens., 24, 1765781, 2003.

Kawamura, K., Tachibana, E., Okuzawa, K., Aggarwal, S. G., Kanaya, Y., and Wang, Z. F.: High abundances of water-soluble dicarboxylic acids, ketocarboxylic acids and $\alpha$-dicarbonyls in the mountaintop aerosols over the North China Plain during wheat burning season, Atmos. Chem. Phys., 13, 8285-8302, doi:10.5194/acp-13-8285-2013, 2013.

Lanz, V. A., Alfarra, M. R., Baltensperger, U., Buchmann, B., Hueglin, C., and Prévôt, A. S. H.: Source apportionment of submicron organic aerosols at an urban site by factor analytical modelling of aerosol mass spectra, Atmos. Chem. Phys., 7, 15031522, doi:10.5194/acp-7-1503-2007, 2007.

Lathem, T. L., Beyersdorf, A. J., Thornhill, K. L., Winstead, E. L., Cubison, M. J., Hecobian, A., Jimenez, J. L., Weber, R. J., Anderson, B. E., and Nenes, A.: Analysis of CCN activity of Arctic aerosol and Canadian biomass burning during summer 2008, Atmos. Chem. Phys., 13, 2735-2756, doi:10.5194/acp-13-27352013, 2013.

Lee, T., Sullivan, A. P., Mack, L., Jimenez, J. L., Kreidenweis, S. M., Onasch, T. B., Worsnop, D. R., Malm, W., Wold, C. E., Hao, W. M., and Collett, J. L.: Chemical smoke marker emissions during flaming and smoldering phases of laboratory open burning of wildland fuels, Aerosol Sci. Tech., 44, 1-5, 2010.

Li, X. H., Wang, S. X., Duan, L., Hao, J. M., Li, Y. S., and Yang, L.: Particulate and trace gas emissions from open burning of wheat straw and corn stover in China, Environ. Sci. Technol., 41, 60526058, 2007.

Lipsky, E. M. and Robinson, A. L.: Effects of dilution on fine particle mass and partitioning of semivolatile organics in diesel exhaust and wood smoke, Environ. Sci. Technol., 40, 155-162, 2006.

Liu, D., Allan, J., Corris, B., Flynn, M., Andrews, E., Ogren, J., Beswick, K., Bower, K., Burgess, R., Choularton, T., Dorsey, J., Morgan, W., Williams, P. I., and Coe, H.: Carbonaceous aerosols contributed by traffic and solid fuel burning at a polluted rural site in Northwestern England, Atmos. Chem. Phys., 11, 1603-1619, doi:10.5194/acp-11-1603-2011, 2011.

Liu, D., Allan, J. D., Young, D. E., Coe, H., Beddows, D., Fleming, Z. L., Flynn, M. J., Gallagher, M. W., Harrison, R. M., Lee, J., Prevot, A. S. H., Taylor, J. W., Yin, J., Williams, P. I., and Zotter, P.: Size distribution, mixing state and source apportionments of black carbon aerosols in London during winter time, Atmos. Chem. Phys. Discuss., 14, 16291-16349, doi:10.5194/acpd-1416291-2014, 2014.

Maenhaut, W., Vermeylen, R., Claeys, M., Vercauteren, J., Matheeussen, C., Roekens, E.: Assessment of the contribution from wood burning to the $\mathrm{PM}_{10}$ aerosol in Flanders, Belgium, Sci. Total Environ., 437, 226-236, 2012. 
Middlebrook, A. M., Bahreini, R., Jimenez, J. L., and Canagaratna, M. R.: Evaluation of composition-dependent collection efficiencies for the aerodyne aerosol mass spectrometer using field data, Aerosol Sci. Tech., 46, 258-271, 2011.

Mohr, C., Huffman, J. A., Cubison, M. J., Aiken, A. C., Docherty, K. S., Kimmel, J. R., Ulbrich, I. M., Hannigan, M., and Jimenez, J. L.: Characterization of primary organic aerosol emissions from meat cooking, trash burning, and motor vehicles with HighResolution Aerosol Mass Spectrometry and comparison with ambient and chamber observations, Environ. Sci. Technol., 43, 2443-2449, 2009.

Mohr, C., DeCarlo, P. F., Heringa, M. F., Chirico, R., Slowik, J. G., Richter, R., Reche, C., Alastuey, A., Querol, X., Seco, R., Peñuelas, J., Jiménez, J. L., Crippa, M., Zimmermann, R., Baltensperger, U., and Prévôt, A. S. H.: Identification and quantification of organic aerosol from cooking and other sources in Barcelona using aerosol mass spectrometer data, Atmos. Chem. Phys., 12, 1649-1665, doi:10.5194/acp-12-1649-2012, 2012.

Ng, N. L., Canagaratna, M. R., Zhang, Q., Jimenez, J. L., Tian, J., Ulbrich, I. M., Kroll, J. H., Docherty, K. S., Chhabra, P. S., Bahreini, R., Murphy, S. M., Seinfeld, J. H., Hildebrandt, L., Donahue, N. M., DeCarlo, P. F., Lanz, V. A., Prévôt, A. S. H., Dinar, E., Rudich, Y., and Worsnop, D. R.: Organic aerosol components observed in Northern Hemispheric datasets from aerosol mass spectrometry, Atmos. Chem. Phys., 10, 4625-4641, doi:10.5194/acp-10-4625-2010, 2010.

Ng, N. L., Herndon, S. C., Trimborn, A., Canagaratna, M. R., Croteau, P. L., Onasch, T. B., Sueper, D., Worsnop, D. R., Zhang, Q., Sun, Y. L., and Jayne, J. T.: An aerosol chemical speciation monitor (ACSM) for routine monitoring of the composition and mass concentrations of ambient aerosol, Aerosol Sci. Technol., 45: 7, 770-784, 2011a.

Ng, N. L., Canagaratna, M. R., Jimenez, J. L., Chhabra, P. S., Seinfeld, J. H., and Worsnop, D. R.: Changes in organic aerosol composition with aging inferred from aerosol mass spectra, Atmos. Chem. Phys., 11, 6465-6474, doi:10.5194/acp-11-64652011, 2011b.

Ng, N. L., Canagaratna, M. R., Jimenez, J. L., Zhang, Q., Ulbrich, I. M., and Worsnop, D. R.: Real-time methods for estimating organic component mass concentrations from aerosol mass spectrometer data, Environ. Sci. Technol., 45, 910-916, 2011c.

Paatero, P.: Least squares formulation of robust non-negative factor analysis, Chemom. Intell. Lab. Syst., 37, 23-35, 1997.

Paatero, P.: The multilinear engine - A table-driven, least squares program for solving multilinear problems, including the n-way parallel factor analysis model, J. Comput. Graph. Stat., 8, 854888, 1999.

Ramanathan, V., Crutzen, P. J, Kiehl, J. T., and Rosenfeld, D.: Atmosphere, aerosols, climate, and the hydrological cycle, Science, 294, 2119-2124, 2001.

Reche, C., Viana, M., Amato, F., Alastuey, A., Moreno, T., Hillamo, R., Teinila, K., Saarnio, K., Seco, R., Penuelas, J., Mohr, C., Prévôt, A. S. H., and Querol, X,.: Biomass burning contributions to urban aerosols in a coastal Mediterranean City, Sci. Total Environ., 427, 175-190, 2012.

Robinson, A. L., Donahue, N. M., Shrivastava, M. K., Weitkamp, E. A., Sage, A. M., Grieshop, A. P., Lane, T. E., Pierce, J. R., and Pandis, S. N.: Rethinking organic aerosols: Semivolatile emissions and photochemical aging, Science, 315, 1259-1262, doi:10.1126/science.1133061, 2007.

Sandradewi, J., Prevot, A. S. H., Szidat, S., Perron, N., Alfarra, M. R., Lanz, V. A., Weingartner, E., and Baltensperger, U.: Using aerosol light absorption measurements for the quantitative determination of wood burning and traffic emission contributions to particulate matter, Environ. Sci. Technol., 42, 3316-3323, 2008.

Sun, J. Y., Zhang, Q., Canagaratna, M. R., Zhang, Y. M., Ng, N. L., Sun, Y. L., Jayne, J. T., Zhang, X. C., Zhang, X. Y., and Worsnop, D. R.: Highly time-and size-resolved characterization of submicron aerosol particles in Beijing using an Aerodyne Aerosol Mass Spectrometer, Atmos. Environ., 44, 131-140, 2010.

Sun, Y.-L., Zhang, Q., Schwab, J. J., Demerjian, K. L., Chen, W.N., Bae, M.-S., Hung, H.-M., Hogrefe, O., Frank, B., Rattigan, O. V., and Lin, Y.-C.: Characterization of the sources and processes of organic and inorganic aerosols in New York city with a high-resolution time-of-flight aerosol mass spectrometer, Atmos. Chem. Phys., 11, 1581-1602, doi:10.5194/acp-11-15812011, 2011a.

Sun, Y. L., Zhang, Q., Schwab, J. J., Chen, W. N., Bae, M. S., Lin, Y. C., Hung, H. M., and Demerjian, K. L.: A case study of aerosol processing and evolution in summer in New York City, Atmos. Chem. Phys., 11, 12737-12750, doi:10.5194/acp11-12737-2011, 2011b.

Sun, Y. L., Wang, Z. F., Dong, H. B., Yang, T., Li, J., Pan, X. L., Chen, P., and Jayne, J. T.: Characterization of summer organic and inorganic aerosols in Beijing, China with an Aerosol Chemical Speciation Monitor, Atmos. Environ., 51, 250-259, 2012.

Sun, Y. L., Wang, Z. F., Fu, P. Q., Yang, T., Jiang, Q., Dong, H. B., Li, J., and Jia, J. J.: Aerosol composition, sources and processes during wintertime in Beijing, China, Atmos. Chem. Phys., 13, 4577-4592, doi:10.5194/acp-13-4577-2013, 2013.

Takegawa, N., Miyakawa, T., Kondo, Y., Jimenez, J. L., Zhang, Q., Worsnop, D. R., and Fukuda, M.: Seasonal and diurnal variations of submicron organic aerosol in Tokyo observed using the Aerodyne aerosol mass spectrometer, J. Geophys. Res., 111, D11206, doi:10.1029/2005JD006515, 2006.

Ulbrich, I. M., Canagaratna, M. R., Zhang, Q., Worsnop, D. R., and Jimenez, J. L.: Interpretation of organic components from Positive Matrix Factorization of aerosol mass spectrometric data, Atmos. Chem. Phys., 9, 2891-2918, doi:10.5194/acp-9-2891-2009, 2009.

Wang, G. H., Kawamura, K., Xie, M. J., Hu, S. Y., Cao, J. J., An, Z. H., Waston J. G., and Chow, J. C.: Organic molecular compositions and size distributions of Chinese summer and autumn aerosols from Nanjing: characteristic haze event caused by wheat straw burning, Environ. Sci. Technol., 43, 6493-6499, 2009a.

Wang, Y. Q., Zhang, X. Y., and Draxler, R. R.: TrajStat: GIS-based software that uses various trajectory statistical analysis methods to identify potential sources from long-term air pollution measurement data, Environ. Modell. Softw., 24, 938-939, 2009 b.

Watson, J. G.: Visibility: Science and regulation, J. Air Waste Manage. Assoc., 52, 628-713, 2002.

Yee, L. D., Kautzman, K. E., Loza, C. L., Schilling, K. A., Coggon, M. M., Chhabra, P. S., Chan, M. N., Chan, A. W. H., Hersey, S. P., Crounse, J. D., Wennberg, P. O., Flagan, R. C., and Seinfeld, J. H.: Secondary organic aerosol formation from biomass burning intermediates: phenol and methoxyphenols, Atmos. Chem. Phys., 13, 8019-8043, doi:10.5194/acp-13-8019-2013, 2013. 
Zhang, H., Ye, X., Cheng, T., Chen, J., Yang, X., Wang, L., and Zhang, R.: A laboratory study of agricultural crop residue combustion in China: Emission factors and emission inventory, Atmos. Environ., 42, 8432-8441, 2008.

Zhang, Q., Worsnop, D. R., Canagaratna, M. R., and Jimenez, J. L.: Hydrocarbon-like and oxygenated organic aerosols in Pittsburgh: insights into sources and processes of organic aerosols, Atmos. Chem. Phys., 5, 3289-3311, doi:10.5194/acp-5-3289-2005, 2005a.

Zhang, Q., Alfarra, M.R. Worsnop, D., Allan, J. D., Coe, H., Cangaratna, M. R., Jimenez, J. L.: Deconvolution and quantification of hydrocarbon-like and oxygenated organic aerosols based on aerosol mass spectrometry, Environ. Sci. Technol., 39, 49384952, doi:4910.1021/es0485681, 2005 b.
Zhang, Q., Jimenez, J. L., Canagaratna, M. R., Allan, J. D, Coe, H., Ulbrich, I. M., Alfarra, M. R., Takami, A., Middlebrook, A. M., Sun, Y. L., Dzepina, K., Dunlea, E., Docherty, K., DeCarlo, P, F., Salcedo, D., Onasch, T., Jayne, J. T., Miyoshi, T., Shimono, A., Hatakeyama, S., Takegawa, N., Kondo, Y., Schneider, J., Drewnick, F., Borrmann, S., Weimer, S., Demerjian, K., Williams, P., Bower, K., Bahreini, R., Cottrell, L., Griffin, R. J., Rautiainen, J., Sun, J. Y., Zhang, Y. M., and Worsnop, D. R.: Ubiquity and dominance of oxygenated species in organic aerosols in anthropogenically-influenced Northern Hemisphere midlatitudes, Geophys. Res. Lett., 34 L13801, doi:10.1029/2007GL029979, 2007.

Zhang, Q., Jimenez, J. L., Canagaratna, M. R., Ulbrich, I. M., Ng, N. L., Worsnop, D. R., and Sun, Y. L.: Understanding atmospheric organic aerosols via factor analysis of aerosol mass spectrometry: a review, Anal. Bioanal. Chem., 401, 3045-3067, 2011. 